\title{
Macroeconomic Instability in the European Monetary System?
}

AMALIA MORALES ZUMAQUERO

SIMÓN SOSVILLA RIVERO

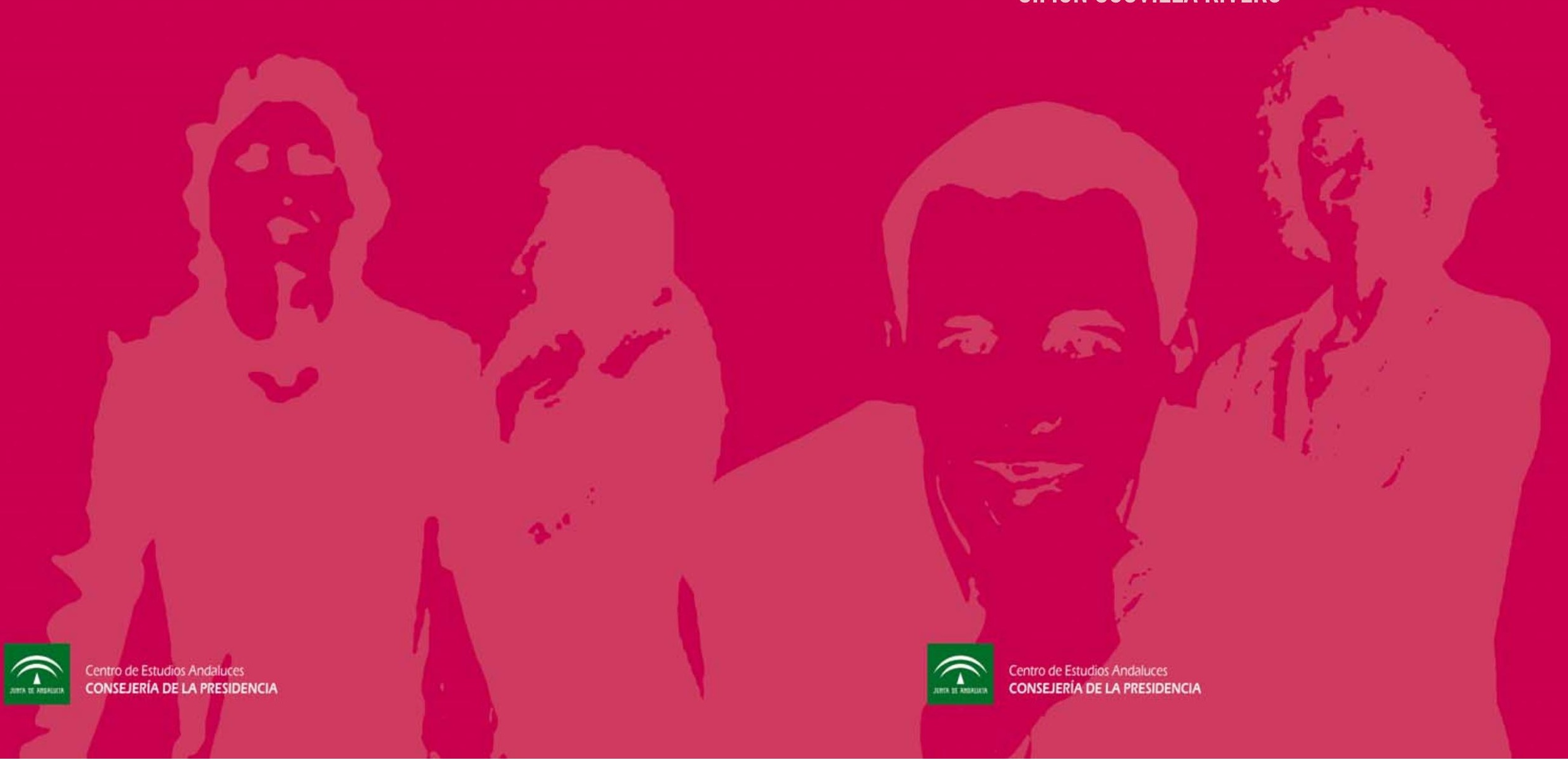


El Centro de Estudios Andaluces es una entidad de carácter científico y cultural, sin ánimo de lucro, adscrita a la Consejería de la Presidencia de la Junta de Andalucía.

El objetivo esencial de esta institución es fomentar cuantitativa y cualitativamente una línea de estudios e investigaciones científicas que contribuyan a un más preciso y detallado conocimiento de Andalucía, y difundir sus resultados a través de varias líneas estratégicas.

El Centro de Estudios Andaluces desea generar un marco estable de relaciones con la comunidad científica e intelectual y con movimientos culturales en Andalucía desde el que crear verdaderos canales de comunicación para dar cobertura a las inquietudes intelectuales y culturales.

Las opiniones publicadas por los autores en esta colección son de su exclusiva responsabilidad 
Documento de Trabajo

Serie Economía E2006/06

\title{
Macroeconomic Instability in the European Monetary System?
}

\author{
Amalia Morales Zumaquero \\ Universidad de Málaga y Centro de Estudios Andaluces \\ Simón Sosvilla Rivero \\ FEDEA, UCM y Centro de Estudios Andaluces
}

\begin{abstract}
RESUMEN
Este trabajo analiza el impacto del establecimiento del Sistema Monetario Europeo (SME) sobre un conjunto de variables macroeconómicas, tales como los tipos de cambio, cantidad de dinero, tipos de interés y precios, para los países participantes en el Mecanismo de Tipos de Cambios (MTC). Se analiza la inestabilidad de dichas variables en términos de la existencia de múltiples cambios estructurales en la varianza de las series. Con este fin, se emplean dos procedimientos: un conjunto de estadísticos, basados en la estimación MCO, desarrollados por Bai y Perron (1998, 2003) y distintos procedimientos basados en Criterios de Información junto con el denominado procedimiento secuencial sugerido por Bai y Perron (2003). Los resultados indican que hay cierta evidencia de cambios estructurales en la volatilidad de las variables investigadas, jugando los realineamientos en el MTC un significativo papel en la reducción de la volatilidad en algunos países y subperíodos. En este sentido, los resultados sugieren que el SME ha contribuido a reducir la volatilidad macroeconómica de los países miembros.
\end{abstract}

Palabras clave: Sistema Monetario Europeo, múltiples cambios estructurales, volatilidad

\section{ABSTRACT}

This paper analyses the impact of the establishment of the European Monetary System (EMS) on a number of macroeconomic variables, such as exchange rates, money, interest rates and prices for member countries participating in the Exchange Rate Mechanism (ERM). We examine the instability in terms of multiple structural breaks in the variance of the series. To that end, we employ two procedures: the OLS-based tests to detect multiple structural breaks, proposed by Bai and Perron $(1998,2003)$ and several procedures based on Information Criterion joint with the so called sequential procedure suggested by Bai and Perron (2003). Results indicate that there is some evidence of structural breaks in volatility across investigated variables, playing the realignments in the ERM a significant role in the reduction of volatility in some countries and sub-periods. In this sense, the results tend to support the hypothesis that the EMS has contributed to reduce the macroeconomic volatility of the member countries.

Keywords: European Monetary System, multiple structural breaks, volatility JEL classification: C12, C22, F31, F33 


\section{Introduction}

The European Monetary System (EMS) was established in 1979 in order to reduce the fluctuations of the nominal exchange rates of the member countries participating in the Exchange Rate Mechanism (ERM). The EMS constituted an important intermediary step to Economic and Monetary Union (EMU) in Europe, the most ambitious experiment since the Bretton-Woods system. With the beginning of EMU in January 1999, the EMS ceased to have effect, being replaced by the new, modified exchange rate mechanism (the so-called ERM-II) designed to maintain exchange-rate stability between the euro and the national currencies of those European countries not participating in EMU.

Previous literature on the EMS can be divided in two groups of papers. The first group has concentrated in analysing the impact of the EMS on a number of economic variables, such as the inflation, interest rates and exchange rate volatility. In this line, Bollerslev (1990), using a GARCH $(1,1)$ model, finds a decrease in conditional volatility and greater coherence among the European exchange rates after the establishment of the EMS, for the German mark, French frank, Italian lira, Swiss frank and British pound before and after the creation of the EMS. Artis and Taylor (1989, 1994) investigate the implications of the ERM on the volatility of exchange rates of member countries. Their results suggest that the ERM has generated a stabilising effect on exchanges rates that has not been bought at the expense of an increase of volatility of the member countries' interest rates. Sarno (1997) extends the analysis by Artis and Taylor (1989, 1994), using the non-parametric technique developed by them. He examines the volatility of exchange rates and interest rates of countries participating in the ERM including data for the crisis period of the EMS from September 1992 onwards. His results show a significant reduction in exchange rate volatility without any "volatility transfer" onto the interest rates.

The second group of papers have just focused on the behaviour of the EMS exchange rates. For example, Fratianni and von Hagen (1990) document that the ERM had a stabilising impact on nominal and real exchange rate. Moreover, Hu, Jiang and Tsoukalas (1997) examine the performance of a number of alternative GARCH/EGARCH models in the pre- and post EMS periods. Their empirical results support for the EGARCH specifications in modelling bilateral exchange rates. Moreover, they find the EMS arrangements are quite effective to reduce the conditional and unconditional volatility in the currency market. More recently, $\mathrm{Hu}$, Jiang and 
Tsoukalas (2004) apply a multivariate $\operatorname{GARCH}(1,1)$ model to all European Union exchange rates, for EMS and non-EMS currencies, in three subperiods: from January 1975 to the establishment of the EMS (March 1979); from March 1979 to the BasleNyborg agreement (September 1987) and from September 1997 to October 1991. Using non-parametric tests their findings suggest that the EMS and, especially, the BasleNyborg agreement have stabilised the European currencies. Finally, Ayuso et al. (1994) and Sosvilla-Rivero et al. (1999) found that exchange rate volatility within the ERM was generally lower after the widening of fluctuations bands in 1995.

This paper is in line with the first set of papers because it tries to analyse the impact of the establishment of the EMS on a number of economic variables, such as bilateral nominal exchange rates, nominal effective exchange rates, real effective exchange rates, money, interest rates and prices for member countries participating in the ERM. However, this study differs substantially from previous one because we examine the instability of this set of macroeconomic variables in terms of multiple structural breaks in the variance of the series. To that end, we employ two procedures: the OLS-based tests to detect multiple structural breaks in mean and/or variance, proposed by Bai and Perron $(1998,2003)$ and several procedures based on Information Criterion joint with the so called sequential procedure suggested by Bai and Perron (2003).

Results suggest that, although there is high heterogeneity between series regarding the dates in which structural breaks in volatility are located, the realignments in the ERM seem to play a significant role in the reduction of volatility in some countries and sub-periods. Therefore, the evidence presented in this paper tends to support the hypothesis that the EMS has contributed to reduce the macroeconomic volatility of the member countries.

The paper is organised as follows. Section 2 briefly reviews the EMS experience, as well as offering a brief account of the economic consequences of adopting a specific exchange rate policy. In Section 3 we present the econometric methodology used to detect structural breaks in volatility. Section 4 describes the data set and reports our empirical results, both for the full period and for sub-periods. Finally, Section 5 offers some concluding remarks. 


\section{The European Monetary System and the Choice of a Fixed Exchange Rate}

\section{Regime}

The aim of the EMS was to establish closer monetary co-operation leading to a zone of monetary stability in Europe. The centrepiece of the EMS was the ERM, establishing a tool for exchange rate stabilization and for encouraging convergence of economic and monetary policies.

The ERM was a system of pegged, but adjustable, exchange rate in which the central parity grid could be altered to take into account changing economic conditions and relative performance of the participant economies. Through a set of monitoring mechanisms (based in economic variables such as interest rates and inflation), the EMS authority tacked the convergence of the member economies and enforce a target zone on their exchange rates. If they decided by mutual agreement that a particular parity could not be defended, realignments of the central rates were permitted. This consensus rule implied that, in effect, each country gave up exclusive control of its own exchange rate. Table 1 shows the main realignments and changes in the EMS during the 1979-1998 period. As can be seen, there were nineteen realignments in the EMS history, being twelve of them prior to the currency turmoil of the sub-period 1992-1993. On the other hand, many changes affected more than one currency, such as the bands increase. In general, high-inflation countries needed to periodically devaluate their currencies with respect to the ECU in order to maintain competitiveness in relation to a low-inflation country such as Germany (see Sosvilla-Rivero and Pérez-Bermejo, 2006).

The choice of a fixed exchange rate regime such as the ERM can significantly affect the behaviour of economic variables and the shock transmission mechanism. However, the consequences of that choice on macroeconomic volatility are still an unsettled issue. From the theoretical point of view, Marston (1985) shows that the effect on volatility depends on several factors, such as the relative magnitudes of demand and supply shocks and of domestic and foreign shocks, while Dornbusch (1983) and Devereux and Engle (1998) underline the role of institutional factors such as wage and price setting rules. Finally, Melvin (1985), Flood and Hodrick (1986) and Berger et al. (2000), among others, point out the important of policy credibility on the economic consequences of an exchange rate choice. From the empirical perspective, there is not unambiguous evidence on the effect of the exchange rate choice on macroeconomic volatility. For instance, Frenkel and Mussa (1980) and Flood and Rose (1995) argue that fixing exchange rates will increase the volatility of economic fundamentals. In contrast, 
Baxter and Stockman (1989) claim that there is little evidence of systematic differences in the behaviour of macroeconomic variables under alternative exchange rate regimes. On the other hand, Ghosh et al. (1997) show that pegged exchange rates are associated with significantly better inflation performance (lower inflation and less variability). Finally, Giavazzi and Giovannini (1989) and Ayuso (1995), among others, argue that the reduction in exchange rate volatility through a formal commitment to exchange rate stability such as the ERM could happen only at the expenses of an increased volatility in interest rates.

\section{Econometric Methodology: Testing for Structural Breaks}

Recent econometric methodology to detect structural breaks is based on testing endogenously the presence of structural breaks of an unknown location. In this sense, three approaches have been mostly developed: the CUSUM-type tests, such as the iterated cumulative sums of squares (ICSS) algorithm by Inclán and Tiao (1994), to test for structural breaks in the variance, the OLS-based tests to detect structural breaks in mean or/and variance (Quandt, 1960; Andrews, 1993; Andrews and Ploberger, 1994; Hansen, 1997; Bai and Perron, 1998, 2003); and, finally, the procedures based on Information Criterion (Liu et al., 1997; Bai and Perron, 1998, 2003). This paper uses the two last approaches ${ }^{1}$.

Bai and Perron $(1998,2003)^{2}$ consider the following multiple linear regression with $m$ breaks ( $m+1$ regimes):

$$
\begin{gathered}
y_{t}=x_{t}^{\prime} \beta+z_{t}^{\prime} \delta_{1}+u_{t}, \quad t=1, \ldots, T_{1}, \\
y_{t}=x_{t}^{\prime} \beta+z_{t}^{\prime} \delta_{2}+u_{t}, \quad t=T_{1}+1, \ldots, T_{2}, \\
\vdots \\
y_{t}=x_{t}^{\prime} \beta+z_{t}^{\prime} \delta_{m+1}+u_{t}, \quad t=T_{m}+1, \ldots, T .
\end{gathered}
$$

In this model, $y_{t}$ is the observed dependent variable at time $t ; x_{t}(p \times 1)$ and $z_{t}$ $(q \times 1)$ are vectors of covariates and $\beta$ and $\delta_{\mathrm{j}} \quad(j=1, \ldots, m+1)$ are the vectors of coefficients, respectively. Finally, $u_{t}$ is the disturbance at time $t$. The break points

\footnotetext{
${ }^{1}$ We concentrate on the last two approaches because the ICSS algorithm present several weaknesses (for example, see Sansó, Aragó and Carrión, 2004 and Valentinyi-Endrész, 2004).

${ }^{2}$ We specially thanks to Bai and Perron for providing us the GAUSS code for making computations.
} 
$\left(T_{1}, \ldots, T_{m}\right)$ are unknown. The purpose is to estimate the unknown regression coefficients and the break points using a sample of $T$ observations.

We consider a pure structural change model $(p=0)$, where all the coefficients are subject to change, from the model in equation (1). In this sense, we specify each series as an $\operatorname{AR}(1)$ process and then, to detect multiple structural breaks in variance, we use the absolute value of the fitted residuals of the AR(1) models ${ }^{3}$. For this analysis we specify $z_{t}=\{1\}$.

To detect for multiple structural breaks, we use the following set of tests developed by Bai and Perron $(1998,2003)^{4}$ : the sup $F$ type test, the double maximum tests and the test for $\ell$ versus $\ell+1$ breaks.

We consider the sup $F$ type test of no structural breaks $(m=0)$ versus the alternative hypothesis that there are $m=k$ breaks. Let $\left(T_{1}, \ldots, T_{k}\right)$ be a partition such that $T_{i}=\left[T \lambda_{i}\right](i=1, \ldots k)$. Let $R$ be the matrix such that $(R \delta)^{\prime}=\left(\delta_{1}^{\prime}-\delta_{2}^{\prime}, \ldots \delta_{k}^{\prime}-\delta_{k+1}^{\prime}\right)$. Define

$$
F_{T}^{*}\left(\lambda_{1}, \ldots \lambda_{k} ; q\right)=\frac{1}{T}\left(\frac{T-(k+1) q-p}{k q}\right) \hat{\delta}^{\prime} R^{\prime}\left(R \hat{V}(\hat{\delta}) R^{\prime}\right)^{-1} R \hat{\delta}
$$

where $\hat{V}(\hat{\delta})$ is an estimate of the variance covariance matrix of $\hat{\delta}$ that is robust to serial correlation and heteroskedasticity. The statistic $F_{T}^{*}$ is the conventional F-statistic for testing $\delta_{1}=\ldots=\delta_{k+1}$ against $\delta_{i} \neq \delta_{i+1}$ for some $i$ given the partition $\left(T_{1}, \ldots, T_{k}\right)$. The supF type test is defined as

$$
\sup F_{T}^{*}(k ; q)=\sup _{\left(\lambda_{1}, \ldots \lambda_{k}\right) \in \Lambda_{\epsilon}} F_{T}^{*}\left(\lambda_{1}, \ldots, \lambda_{k} ; q\right)
$$

A simpler version of this statistic uses the estimates of the break dates obtained from the global minimization of the sum of squared residuals. If we denote these estimates by $\hat{\lambda}_{i}=\hat{T}_{i} / T$ for $i=1, \ldots k$, the test will be then

$$
\sup F_{T}(k ; q)=F_{T}\left(\hat{\lambda}_{1}, \ldots, \hat{\lambda}_{k} ; q\right)
$$

\footnotetext{
${ }^{3}$ Similarly, Stock and Watson (2002) use the absolute value of the fitted residuals of a VAR model to analyse changes in variance. Alternatively, Valentinyi-Endrész (2004) use the squared errors from a AR(1)-GARCH(1,1) model to compute changes in variance.

${ }^{4}$ For a further analysis see Bai and Perron (1998, 2003).
} 
The null hypothesis of the double maximum tests, UDmax and WDmax, is no structural breaks against an unknown number of breaks given some upper bound $\mathrm{M}$. The first one is an equal weighted version defined by

$$
\operatorname{UDmax}_{T}^{*}(M ; q)=\max _{1 \leq m \leq M} \sup _{\left(\lambda_{1}, \ldots \lambda_{m}\right) \in \Lambda_{\epsilon}} F_{T}^{*}\left(\lambda_{1}, \ldots \lambda_{m} ; q\right)
$$

We use the asymptotically equivalent version is

$$
\operatorname{UDmax}_{T}(M ; q)=\max _{1 \leq m \leq M} F_{T}\left(\hat{\lambda}_{1}, \ldots \hat{\lambda}_{m} ; q\right)
$$

where $\hat{\lambda}_{j}=\hat{T}_{j} / T$ for $j=1, \ldots m$ are the estimates of the break points obtained using the global minimization of the sum of squared residuals.

The second one applies weights to the individuals tests such that the marginal pvalues are equal across values of $m$. This version is denoted

$$
W D \max F_{T}^{*}(M ; q)=\max _{1 \leq m \leq M} \frac{c(q, \alpha, 1)}{c(q, \alpha, m)} \sup _{\left(\lambda_{1}, \ldots \lambda_{m}\right) \in \Lambda_{\epsilon}} F_{T}^{*}\left(\lambda_{1}, \ldots \lambda_{m} ; q\right)
$$

We use the asymptotically equivalent version

$$
\operatorname{WDmax}_{T}(M ; q)=\max _{1 \leq m \leq M} \frac{c(q, \alpha, 1)}{c(q, \alpha, m)} F_{T}\left(\hat{\lambda}_{1}, \ldots \hat{\lambda}_{m} ; q\right)
$$

Finally, we use the test for $\ell$ versus $\ell+1$ breaks, the labelled sup $F_{T}(\ell+1 / \ell)$ test. The methods amounts to the application of $(\ell+1)$ test of the null hypothesis of no structural change versus the alternative hypothesis of a single change. The test is applied to each segment containing the observations $\hat{T}_{i-1}$ to $\hat{T}_{i} i=1, \ldots,(\ell+1)$.

To run these tests is necessary to decide the minimum distance between two consecutive breaks, $h$, that it is obtain as the integer part of a trimming parameter, $\varepsilon$, multiply for the number of observations $T$ (we use $\varepsilon=0.15$ and allow up 5 breaks for the full sample analysis and $\varepsilon=0.20$ and allow up 3 breaks for the sub-period analysis).

To select the dimension of the models, following the suggestions by Bai and Perron (2003), we consider the Bayesian Information Criterion (BIC) developed by Yao (1988), and a modified Schwarz' criterion proposed by Liu, Wu and Zidek (1994), the LWZ criterion. In addition, we employ the method suggested by Bai and Perron (1998) based on the sequential application of the sup $F_{T}(\ell+1 / \ell)$ test, the sequential procedure, 
SP. This method starts by estimating a model with a small number of breaks that are thought to be necessary. Then perform parameter-constancy tests for each sub-periods, adding a break to a sub-period associated with a rejection with the test sup $F_{T}(\ell+1 / \ell)$. This process in repeated increasing $\ell$ sequentially until the test $\sup F_{T}(\ell+1 / \ell)$ fails to reject the null hypothesis of no additional structural breaks.

\section{Data and Empirical Results}

\subsection{Data}

In the empirical analysis, we use monthly data for a set of macroeconomic variables such as exchange rates, money, interest rates and prices. In particular, we use two set of data. The first one covers from 1957.1 to1998.12, the full period ${ }^{5}$, for bilateral nominal exchange rate against the Deustchemark, nominal effective exchange rate and real effective exchange rate series; for money (M3) series; for money market rate series; and for consumer price series for EMS member countries: Germany, France, The Netherlands, Italy, Belgium, Denmark, Ireland, United Kingdom, Spain, Portugal, Austria and Finland.

The second data set covers different periods depending on a particular country is in or out the EMS (see Table 2). The analysis by sub-period is done for nominal exchange rate and nominal effective exchange rate series; money market rate series and consumer price series ${ }^{6}$.

All data used in this paper comes from the IMF International Financial Statistics of the International Monetary Fund, except for the M3 variable, that was kindly provided by the Bank of Spain.

\subsection{A General Overview: The Full Period}

The Bai and Perron's $(1998,2003)$ methodology have been applied to the monthly data series of bilateral nominal exchange rate against the Deustchemark, nominal effective exchange rate, real effective exchange rate; money (M3), money market rate and consumer price, covering mostly, from 1957.1 to1998.12, the full period.

The results are displayed in Tables 3 to 8, offering four sets of information. In the first place, we present in Columns 2 to 6 the numerical results of the statistics we

\footnotetext{
${ }^{5}$ This full period differs between countries depending on the data availability.

${ }^{6}$ For this analysis we have chosen the variables with the most homogenous sample period.
} 
have described in Section $3^{7}$. In the second place, we show in Columns 7 to 9 the number of breaks selecting by the BIC, LWZ and SP. To select the number of breaks of the final model, we follow the practical recommendations by Bai and Perron (2003). When the number of breaks is different between procedures, we concentrate in the number that the SP indicates (the SP works best in selecting the number of breaks than the others). Moreover, the performance of the SP can be improved looking at the UDmax or WDmax tests to see if at least a break is present. Then, the number of breaks can be decided based on an examination of the sup $F_{T}(\ell+1 / \ell)$ statistics ${ }^{8}$. In the third place, we present in Columns 10 to 12 the estimated final model and, finally, in the last columns, the dates of the breaks are reported. Four central messages are derived from these results: (1) there is some evidence of structural breaks in volatility across investigated series, being one or two the number of break points more frequently detected; (2) the detected instability occurs, in almost all countries and series, in dates in which the specific country was not still a member of the EMS; (3) there is heterogeneity between series regarding the dates in which the break points are located; and (4) there is marginal evidence suggesting that the realignments in the ERM seem to play a significant role in the reduction of volatility in some countries and sub-periods.

Let us now discuss the results obtained for the different variables examined in this paper. Regarding the bilateral nominal exchange rate against the Deustchemark series (Table 3), results show, on one hand, that there are two out of the total of eleven currencies with three structural breaks in variance, six out of eleven currencies with two breaks in variance, two out of eleven currencies with one break and, finally, one currency out of eleven with no evidence of instability. Therefore, our results suggest the existence of at least two breaks in the volatility of bilateral nominal exchange rate during the examined period. Furthermore, the first detected break point is located by the end of 1960's or at the beginning of 1970's. The only exception is France, where there is evidence of increase volatility before the realignment that took place in 1983. This break in nominal volatility can be associated with the breakdown of the Bretton Woods System and, as can be seen in the estimated means over each sub-period, there is evidence of a significant increase after these events. The second break is mostly detected at the end of 1970's and at the beginning of 1980. For Belgium, Denmark, Italy

\footnotetext{
${ }^{7}$ In order to save space, we only offer in the tables the numerical results of four of the statistics we have described in Section 3. The other results are available from the authors upon request.

${ }^{8}$ See Bai and Perron (2003) for a further analysis.
} 
and the Netherlands, these break points could be associated to realignments in the EMS, and resulted in a reduction in volatility. For the rest of countries, the breaks are located in dates in which the specific country was not a member of the EMS, suggesting the differences in the estimated means over sub-periods a decrease in volatility. Finally, it is worth notice that both Ireland and Italy registered a further increase in volatility after the 1992 monetary turmoil, reflecting the credibility loses in the Irish pound after the suspension of the participation of the sterling and the speculative attacks on the Italian Lira that caused its temporary withdraw from the ERM.

As for the volatility in nominal effective exchange rate, results in Table 4 also suggest the existence of at least two break points: one located at the end of 1960's or at the beginning of 1970's and the other at the beginning of the 1980's. Once again, the first break can be associated with the breakdown of the Bretton Woods System and the second with realignments in the EMS. Furthermore, the first break implied an increase in volatility, while the second meant a reduction in volatility. Interestingly, the pattern seems to change when examining the real effective exchange rate series. As can be seen in Table 5, the results suggest a first reduction in volatility around the realignments that took place in the 1980's and a further decrease in the Austrian schilling, the Italian lira and the Spanish peseta after the widening of the fluctuation bands in 1995. This last finding is consistent with the gains in credibility detected for these currencies during this period (see Ledesma-Rodríguez et al., 2005).

Turning now to the money (M3) series, in Table 6 we can observe that there is very few evidence of instability in the variance: there are in total just six breaks and three out of them took place in a date in which the specific country was not a member of the EMS. Nevertheless, for France and the Netherlands the differences in the estimated means suggest a significant reduction in volatility when the Pound sterling joined the ERM and before the Dutch guilder realignment in 1985, respectively.

With regard to the money market rate data (Table 7), two out of the total eleven series exhibit three structural breaks, three present two breaks, for five we find evidence of a single break and one series the procedure do not detect any evidence of instability. It is interesting to notice that fourteen out of the total of seventeen detected break points took place in dates in which the specific country was not still a member of the EMS. However, we do find a significant decrease in volatility in Germany before the Deustchemark realignment in 1981, in Denmark between the first and the second 
realignment in the Danish krone that took place in 1981, and in Italy after the Italian lira realignment the same year.

When we consider the consumer price series, results in Table 8 indicate that only three out of a total of twelve detected breaks took place in a date in which the specific country was in the EMS. Two of these breaks occurred in Denmark (after the Italian lira realignment in 1981 and after UKL joined the ERM in 1990) and one in France (being associated with the French franc realignment in 1983). In all three cases, the differences in the estimated means suggest a significant reduction in volatility. As can be seen, there are a great deal of heterogeneity regarding the dates in which the detected break points are located.

\subsection{A Further Analysis: Sub-periods}

With the aim of obtaining additional evidence on the role played by the EMS regarding the stability of macroeconomic variables in member countries, we apply the Bai and Perron's $(1998,2003)$ methodology to our time series of bilateral nominal exchange rate against the Deustchemark, nominal effective exchange rate, money market rate and consumer price series by sub-periods. In particular, we make the analysis distinguishing between different sub-periods depending on a specific country was in or out the EMS (see specific periods for each country in Table 2).

Results by sub-periods are illustrated in Tables 9 to 12. These results seem to suggest that (1) there is some evidence of instability in the variance during the period/s in which a particular country was member of the EMS; and (2) the detected break points are either related with the realignments in the ERM or with the crises of the EMS at the beginning-mid of 1990’s.

Results obtained for the bilateral nominal exchange rate against the Deustchemark by sub-periods are shown in Table 9. As can be seen, in six out of the eleven currencies considered in this paper there is no evidence of instability in the variance during the period in which the country was in the EMS. For the rest, the number of detected break is either one or two. Regarding the break dates, three break points are repeated across currencies. The first one is located around the end of 1960 (mostly around 1967 and 1968) and could be associated with the third realignment that took place in the Bretton Woods System. The second common break point appears around 1972 and 1973 corresponding with the Smithsonian realignment. Finally, the final common break that occurs in the beginning or in the mid of 1990's could be 
closely connected with the crises in the EMS. It is worth noticing that while in the first two break dates the differences in the estimated means suggest a significant increase in volatility after such events, in the last one there is a reduction in volatility (except for the Irish and British cases).

For the nominal effective exchange rates series (Table 10), in six out of eleven countries there is no evidence of instability during the EMS sub-period. For the rest, the estimated means reveal a reduction in volatility in the Danish krone after its realignment in 1983, in the Spanish peseta after its realignment in 1995, in the Italian lira after rejoining the ERM in 1996, and in the Austrian schilling and the Portuguese escudo in 1997. Moreover, for nine out of eleven currencies examined there is also of a break point located around 1971 and 1972 that could be associated, once again, with the Smithsonian realignment.

Regarding interest rates, in Table 11 we see that in seven out of eleven countries studied in this paper we do find evidence of instability during the EMS sub-period. For these countries, in ten out of the fourteen instability events detected, there was a reduction in volatility generally associated with realignments.

Finally, as can be seen in Table 12, for the consumer price index series in six out of the ten countries there is evidence of instability in the variance during the period in which the country was in the EMS. For those countries we find one break, except for Germany, where two breaks are detected. The break point is located in the mid-1980's in Belgium, Germany, France (been again closely connected with realignments and associated with reductions in volatility), while for Portugal and Spain it is located at the mid-1990’s (implying this time an increase in volatility).

[Table 12, here]

\section{Concluding Remarks}

The purpose of our paper has been to contribute to the debate on the stabilising effects of a fixed exchange rate regime such as the ERM. To that end, we have examined the instability in terms of multiple structural breaks in the variance in the time series of several key macroeconomic variables: bilateral nominal exchange rates, nominal effective exchange rates, real effective exchange rates, money, interest rates and prices. In particular, we have presented the results of applying alternative two 
procedures: the OLS-based tests to detect multiple structural breaks, proposed by Bai and Perron (1998, 2003) and several procedures based on Information Criterion joint with the so called sequential procedure suggested by Bai and Perron (2003).

The main results are as follows. First, we found some evidence of structural breaks in volatility across investigated variables. Secondly, there is high heterogeneity between series regarding the dates in which the break points are located. Finally, the realignments in the ERM seem to play a significant role in the reduction of volatility in some countries and sub-periods.

Our results are consistent with the evolution of the nature of the EMS [see, e. g. De Grauwe (2000) or Ledesma-Rodríguez et al. (2005)]. First, the relatively large fluctuation bands in the EMS (compared to those in the Bretton Woods system), together with relatively small and frequent realignments, helped to reduce the size of speculative capital movements and stabilised the system during the 1980s. In the early 1990s, however, the evolution of the EMS into a truly fixed exchange rate system with almost perfect capital mobility led to credibility losses in a context of policy conflict among EMS countries about how to face the severe recession experienced in 1992-93 ${ }^{9}$. Finally, after the crisis of 1993, the EMS changed its nature in drastic ways. The EMS gained credibility with the enlargement of the fluctuation bands to $\pm 15 \%$ (reducing the scope for large speculative gains) and with the fixed exchange rate commitment among potential EMU-member countries. As a result, speculation became a stabilising factor and the market rates converged closer and closer to the fixed conversion rates, although the world was hit by a major crisis during the second half of 1998.

All in all, the evidence presented in this paper tends to support the hypothesis that the EMS has contributed to reduce the macroeconomic volatility of the member countries.

\footnotetext{
${ }^{9}$ The Basle-Nyborg Agreement in September 1987 strengthened interventions in the foreign exchange market, implying the acceptance of the Deutschemark as the anchor of the system (Braga de Macedo et al., 2001).
} 


\section{References}

ANDREWS, D. (1993): “Test for Parameter Instability and Structural Change with Unknown Change Point”, Econometrica 61: 821-856.

ANDREWS, D. and PLOBERGER, W. (1994): "Optimal Tests When a Nuisance Parameter is Present Only Under the Alternative”, Econometrica 62: 1383-1414.

ARTIS, M.J. and TAYLOR, M. P. (1989): “The Achievements of the EMS”, Economic and Social Review 20: 121-145.

ARTIS, M.J. and TAYLOR, M. P. (1994): “The Stabilizing Effect of the ERM on Exchange Rates and Interest Rates: Some Nonparametric Tests”, IMF Staff Papers 41: 123-148.

AYUSO, J. (1995): "Is There a Trade-Off Between Exchange Rate Risk and Interest Rate Risk?”, Bank of Spain Working Paper 9529.

AYUSO, J., PÉREZ-JURADO, M. and RESTOY, F. (1994): "Is Exchange Rate Risk Higher in the E.R.M. after the Widening of Fluctuation Bands?”, Bank of Spain Working Paper 9419.

BAI, J. and PERRON, P. (1998): "Estimating and Testing Linear Models with Multiple Structural Changes”, Econometrica 66: 47-78.

BAI, J. and PERRON, P (2003): "Computation and Analysis of Multiple Structural Change Models”, Journal of Applied Econometrics 18: 1-22.

BAXTER, M. and STOCKMAN, A. C. (1989): "Business Cycles and the Exchange Rate Regime: Some International Evidence”, Journal of Monetary Economics 23: 377400.

BERGER, H., DE HAAN, J. and STURM, J.-E. (2000): “An Empirical Investigation into Exchange Rate Choice and Exchange Rate Volatility”, CESifo Working Paper 263.

BOLLERSLEV, T. (1990): "Modelling the Coherence in Short-run Nominal Exchange Rates: a Multivariate Generalized ARCH Model”, Review of Economics and Statistics 72: 498-505.

BRAGA DE MACEDO, J. COHEN, D. And REISEN, H. (2001): Don't Fix, Don't Float (Paris: Development Centre Studies, Organisation for Economic Co-operation and Development).

DE GRAUWE, P. (2000): Economics of Monetary Union, Fourth edition (Oxford: Oxford University Press). 
DEVEREUX, M. and ENGLE, C. (1998): "Fixed vs. Floating Exchange Rates: How Price Affect the Optimal Choice of Exchange-Rate Regime”, NBER Working Paper 6867.

DORNBUSCH, R. (1983): “Flexible Exchange Rates and Interdependence”, IMF Staff Papers 30: 3-30

FLOOD, R. P. and HODRICK, R. J. (1986): "Real Aspects of Exchange Rate Regime Choice with Collapsing Fixed Rates”, Journal of International Economics 21: 215-232.

FLOOD, R. P. and ROSE, A. K. (1995): "Fixing Exchange Rates: A Virtual Quest for Fundamentals”, Journal of Monetary Economics 36: 3-37.

FRENKEL, J. A. and MUSSA, M. L. (1980): “The Efficiency of the Foreign Exchange Market and Measures of Turbulence", American Economic Association Papers and Proceedings, 70: 374-381.

FRATIANNI, M. and VON HAGEN, J. (1990): “The European Monetary System Ten Years After”, Carnegie-Rochester Conference Series on Public Policy 39: 221-381.

GHOSH, A. R., GULDE, A.-M., OSTRY, J. D. and WOLF, H. C. (1997): "Does the Nominal Exchange Rate Regime Matter?”, NBER Working Paper No. 5874

GIAVAZZI, F. and GIOVANNINI, A (1989): Limiting Exchange Rate Flexibility (Cambridge, Mass.: The MIT Press).

HANSEN, B. E. (1997): “Approximate Asymptotic P Values for Structural-Change Tests”, Journal of Business and Economic Statistics 15: 60-67.

HU, M.Y., JIANG, C. X., TSOUKALAS, C. (1997): “The European Exchange Rates Before and After the establishment of the European Monetary System”, Journal of International Financial Markets, Institutions and Money 7: 235-253.

HU, M.Y., JIANG, C. X., TSOUKALAS, C. (2004): "The Volatility Impact of the European Monetary System on Member and Non-member Currencies”, Applied Financial Economics 14: 313-325.

INCLAN C. and TIAO, G. C. (1994): "Use of Cumulative Sums of Squares for Retrospective Detection of Changes of Variance", Journal of American Statistical Association 89: 913-923.

LEDESMA-RODRÍGUEZ, F., NAVARRO-IBÁÑEZ, M., PÉREZ-RODRÍGUEZ, J. and Sosvilla-Rivero, S. (2005): "Assessing the Credibility of a Target Zone: Evidence from the EMS", Applied Economics 37: 2265-2287.

LIU, J.S., Wu, S., and ZIDEK, J.V. (1997): “On Segmented Multivariate Regressions”, Statistica Sinica 7: 497-525. 
MARSTON, R. C. (1985): “Stabilization Policies in Open Economies”, in R. W. Jones and P. B. Kenen (eds.): Handbook of International Economics, Vol. 2 (Amsterdam: North-Holland) 859-916.

MELVIN, M. (1985): "The Choice of an Exchange Rate Regime and the Macroeconomic Stability”, Journal of Money, Credit and Banking 17: 467-478.

QUANDT, R.E. (1960): “Tests of the Hypothesis that a Linear Regression System Obeys Two Separate Regimes”, Journal of American Statistical Association 55: 324330.

SARNO, L. (1997): "Exchange Rate and Interest Rate Volatility in the European Monetary System: Some Further Results”, Applied Financial Economics 7: 255-263.

SANSÓ, A., ARAGÓ, V., and CARRIÓN, J.L. (2004): "Testing for Changes in the Unconditional Variance of Financial Time Series”, Revista de Economía Financiera 4.

SOSVILLA-RIVERO, S. and PÉREZ-BERMEJO, F. (2006): "Credibility and Duration in Target Zones: Evidence from the EMS", in A. Morales-Zumaquero (ed.): International Macroeconomics: Recent Developments (New York: Nova Science Publishers).

SOSVILLA-RIVERO, S., FERNÁNDEZ-RODRÍGUEZ, F. and BAJO-RUBIO, O. (1999): "Exchange Rate Volatility in the EMS before and after the Fall", Applied Economics Letters 6: 717-722.

STOCK, J.H. and WATSON, M.W. (2002): "Has the Business Cycle Changed and Why?”, NBER Working Paper 9127.

VALENTINYI-ENDRÉSZ, M. (2004): “Structural Breaks and Financial Risk Management”, MNB Working Paper 11. 
Table 1: Main realignments and changes in the ERM (1979-1998)

\begin{tabular}{|c|c|}
\hline 13.03.1979 & $\begin{array}{l}\text { ERM starts to operate with the BFR, DKR, DM, FF, IRL, LIT and HFL. } \\
\text { They are in the narrow band ( } \pm 2.25 \% \text { fluctuation), except the LIT in the wide band } \\
\text { ( } \pm 6 \% \text { fluctuation). }\end{array}$ \\
\hline 24.09.1979 & Realignment (DKR -3\%, DM +2\%) \\
\hline 30.11 .1979 & Realignment (DKR -5\%) \\
\hline 23.03.1981 & Realignment (LIT -6\%) \\
\hline 5.10 .1981 & Realignment (DM +5.5\%, FF -3\%, HFL +5.5\%, LIT -3\%) \\
\hline 22.02.1982 & Realignment (BFR -8.5\%, DKR -3\%) \\
\hline 14.06.1982 & Realignment (DM +4.25\%, FF -5.75\%, HFL +4.25\%, LIT -2.75\%) \\
\hline 22.03.1983 & $\begin{array}{l}\text { Realignment (BFR +1.5\%, DKR +2.5\%, DM +5.5\%, FF -2.5\%, IRL -3.5\%, } \\
\text { HFL +3.5\%, LIT -2.5\%) }\end{array}$ \\
\hline 22.07.1985 & $\begin{array}{l}\text { Realignment (BFR +2\%, DKR +2\%, DM +2\%, FF +2\%, IRL +2\%, HFL +2\%, } \\
\text { LIT -6\%) }\end{array}$ \\
\hline 7.04.1986 & Realignment (BFR +1\%, DKR +1\%, DM +3\%, FF -3\%, HFL +3\%) \\
\hline 4.08.1986 & Realignment (IRL -8\%) \\
\hline 12.01.1987 & Realignment (BFR +2\%, DM +3\%, HFL +3\%) \\
\hline 19.06.1989 & The PTA joins the ERM with the wide band ( $\pm 6 \%)$ \\
\hline 8.01 .1990 & The LIT joins the narrow band ( \pm 2.25\%). Realignment (LIT $-3.6774 \%)$ \\
\hline 8.10 .1990 & The UKL joins the ERM with the wide band ( $\pm 6 \%)$ \\
\hline 6.04 .1992 & The ESC joins the ERM with the wide band $( \pm 6 \%)$ \\
\hline 14.09.1992 & $\begin{array}{l}\text { Realignment (BFR +3.5\%, DKR +3.5\%, DM +3.5\%, ESC +3.5\%, FF +3.5\%, IRL +3.5\%, } \\
\text { HFL +3.5\%, LIT -3.5\%, PTA +3.5\%, UKL +3.5\%) }\end{array}$ \\
\hline 17.09.1992 & The UKL and the LIT suspend their participation in the ERM. Realignment (PTA -5\%) \\
\hline 23.11 .1992 & Realignment (ESC -6\%, PTA -6\%) \\
\hline 1.02 .1993 & Realignment (IRL -10\%) \\
\hline 14.05.1993 & Realignment (ESC -6.5\%, PTA -8\%) \\
\hline 2.08 .1993 & The ERM fluctuation bands are widened to $\pm 15 \%$, except for the DM and the HFL \\
\hline 9.01 .1995 & The ATS joins the ERM with the new wide band $( \pm 15 \%)$ \\
\hline 6.03 .1995 & Realignment (ESC -3.5\%, PTA -7\%) \\
\hline 14.10.1996 & The FIM joins the ERM with the new wide band ( $\pm 15 \%)$ \\
\hline 25.11 .1996 & The LIT re-joins the ERM with the new wide band $( \pm 15 \%)$ \\
\hline 16.03 .1998 & Realignment (IRL +3\%). The DR joins the ERM with the new wide band ( $\pm 15 \%$ ) \\
\hline
\end{tabular}

Note: ATS, BFR, DKR, DM, DR, ESC, FF, FIM, HFL, IRL, LIT, PTA and UKL denote, respectively, the Austrian schilling, the Belgian franc, the Danish krone, the Deustchemark, the Greek drachma, the Portuguese escudo, the French franc, the Finnish markka, the Dutch guilder, the Irish pound, the Italian lira, the Spanish peseta and the Pound sterling. 
Table 2. Sub-periods by Countries ${ }^{\mathrm{a}}$

\begin{tabular}{|l|c|c|c|c|}
\hline & Before EMS & $\begin{array}{l}\text { During EMS } \\
\text { Country out }\end{array}$ & $\begin{array}{l}\text { During EMS } \\
\text { Country in }\end{array}$ & $\begin{array}{l}\text { During EMS } \\
\text { Country out }\end{array}$ \\
\hline Germany & $1957: 1-1979: 2$ & - & $1979: 3-1998: 12$ & - \\
\hline Austria & $1957: 1-1979: 2$ & $1979: 3-1994: 12$ & $1995: 1-1998: 12$ & - \\
\hline Belgium & $1957: 1-1979: 2$ & - & $1979: 3-1998: 12$ & - \\
\hline Denmark & $1957: 1-1979: 2$ & - & $1979: 3-1998: 12$ & - \\
\hline Spain & $1957: 1-1979: 2$ & $1979: 3-1989: 5$ & $1989: 6-1998: 12$ & - \\
\hline Finland & $1957: 1-1979: 2$ & $1979: 3-1996: 9$ & $1996: 10-1998: 12$ & - \\
\hline France & $1957: 1-1979: 2$ & - & $1979: 3-1998: 12$ & - \\
\hline Irland & $1957: 1-1979: 2$ & - & $1979: 3-1998: 12$ & - \\
\hline Italy & $1957: 1-1979: 2$ & & $1979: 3-1992: 9$ & $1992: 10-1998: 12$ \\
\hline Netherlands & $1957: 1-1979: 2$ & - & $1979: 3-1998: 12$ & - \\
\hline Portugal & $1957: 1-1979: 2$ & $1979: 3-1992: 3$ & $1992: 4-1998: 12$ & - \\
\hline United Kingdom & $1957: 1-1979: 2$ & $1979: 3-1990: 9$ & $1990: 10-1992: 9$ & $1992: 10-1998: 12$ \\
\hline
\end{tabular}

Notes.

a. The period before EMS starts in 1957.1 for all variables except for the money market rates that starts in 1972.1. 
Table 3. Multiple Structural Changes in Variance: Nominal Exchange Rates, Full Sample

\begin{tabular}{|c|c|c|c|c|c|c|c|c|c|c|c|c|c|c|c|}
\hline \multirow[b]{3}{*}{ NER } & & & & & & \multicolumn{3}{|c|}{ Specifications: } & $z_{t}=\{1\}$ & $q=1$ & $p=0$ & $\varepsilon=0.1$ & \multicolumn{2}{|c|}{$m=5$} & \\
\hline & \multicolumn{5}{|c|}{ Tests $^{\mathrm{a}}$} & \multicolumn{3}{|c|}{ Number of Breaks ${ }^{b}$} & \multicolumn{4}{|c|}{ Final Model: Parameter Estimates } & \multicolumn{3}{|c|}{ Dates } \\
\hline & $\operatorname{SupF}_{T}(1)$ & $\operatorname{SupF}_{T}(2 / 1)$ & $\operatorname{SupF}_{T}(3 / 2)$ & $\operatorname{SupF}_{T}(4 / 3)$ & $\operatorname{SupF}_{T}(5 / 4)$ & SP & LWC & BIC & $\hat{\delta}_{1}$ & $\hat{\delta}_{2}$ & $\hat{\delta}_{3}$ & $\hat{\delta}_{4}$ & $\hat{T}_{1}$ & $\hat{T}_{2}$ & $\hat{T}_{3}$ \\
\hline $\begin{array}{l}\text { ATS/DM }^{\mathrm{C}} \\
\text { 1957.1-1998.12 }\end{array}$ & $14.71^{*}$ & $12.03^{* *}$ & $11.47^{* *}$ & - & - & 2 & 0 & 2 & $\begin{array}{c}0.002 \\
(0.0004)\end{array}$ & $\begin{array}{c}0.004 \\
(0.0004) \\
\end{array}$ & $\begin{array}{c}0.002 \\
(0.0003) \\
\end{array}$ & - & 1968.4 & 1980.6 & - \\
\hline $\begin{array}{c}\text { BFR/DM } \\
\text { 1957.1-1998.12 }\end{array}$ & $19.26^{*}$ & 28.03* & - & - & - & 2 & 0 & 2 & $\begin{array}{c}0.002 \\
(0.0005)\end{array}$ & $\begin{array}{c}0.006 \\
(0.0004)\end{array}$ & $\begin{array}{c}0.003 \\
(0.0004)\end{array}$ & - & 1968.1 & 1983.2 & - \\
\hline $\begin{array}{l}\text { DKR/DM } \\
\text { 1957.1-1998.12 }\end{array}$ & $41.23^{*}$ & $15.31^{*}$ & - & - & - & 2 & 0 & 2 & $\begin{array}{c}0.003 \\
(0.0006)\end{array}$ & $\begin{array}{c}0.008 \\
(0.0005) \\
\end{array}$ & $\begin{array}{c}0.005 \\
(0.0004) \\
\end{array}$ & - & 1967.9 & 1979.9 & - \\
\hline $\begin{array}{l}\text { PTA/DM } \\
\text { 1957.1-1998.12 }\end{array}$ & - & $12.79^{* *}$ & - & - & - & 2 & 0 & 2 & $\begin{array}{c}0.009 \\
(0.001) \\
\end{array}$ & $\begin{array}{c}0.02 \\
(0.002) \\
\end{array}$ & $\begin{array}{c}0.01 \\
(0.001) \\
\end{array}$ & - & 1973.3 & 1980.3 & - \\
\hline $\begin{array}{l}\text { FIM/DM } \\
\text { 1957.1-1998.12 }\end{array}$ & - & - & - & - & - & 0 & 0 & 0 & - & - & - & - & - & - & - \\
\hline $\begin{array}{c}\text { FF/DM } \\
\text { 1957.1-1998.12 }\end{array}$ & $23.36^{*}$ & - & - & - & - & 1 & 0 & 2 & $\begin{array}{c}0.01 \\
(0.0008) \\
\end{array}$ & $\begin{array}{c}0.005 \\
(0.001) \\
\end{array}$ & - & - & 1983.2 & - & - \\
\hline $\begin{array}{c}\text { IRL/DM } \\
\text { 1957.1-1998.12 }\end{array}$ & $55.43^{*}$ & $20.73^{*}$ & $19.06^{*}$ & - & - & 3 & 2 & 3 & $\begin{array}{c}0.004 \\
(0.001) \\
\end{array}$ & $\begin{array}{c}0.02 \\
(0.001) \\
\end{array}$ & $\begin{array}{c}0.005 \\
(0.001) \\
\end{array}$ & $\begin{array}{c}0.01 \\
(0.001)\end{array}$ & 1967.9 & 1978.9 & 1992.8 \\
\hline $\begin{array}{c}\text { LIT/DM } \\
\text { 1957.1-1998.12 }\end{array}$ & $57.37 *$ & $15.81^{*}$ & $17.00^{*}$ & - & - & 3 & 2 & 3 & $\begin{array}{c}0.005 \\
(0.0009) \\
\end{array}$ & $\begin{array}{c}0.02 \\
(0.001) \\
\end{array}$ & $\begin{array}{c}0.007 \\
(0.001)\end{array}$ & $\begin{array}{c}0.02 \\
(0.001) \\
\end{array}$ & 1972.10 & 1979.11 & 1992.7 \\
\hline $\begin{array}{l}\text { HFL/DM } \\
\text { 1957.1-1998.12 }\end{array}$ & $19.26^{*}$ & $28.03^{*}$ & - & - & - & 2 & 0 & 2 & $\begin{array}{c}0.002 \\
(0.0005) \\
\end{array}$ & $\begin{array}{c}0.006 \\
(0.0004) \\
\end{array}$ & $\begin{array}{c}0.002 \\
(0.0004) \\
\end{array}$ & - & 1968.1 & 1983.2 & - \\
\hline $\begin{array}{c}\text { ESC/DM } \\
\text { 1957.1-1998.12 }\end{array}$ & $41.55^{*}$ & $9.68 * * *$ & $17.13^{*}$ & - & - & 2 & 0 & 2 & $\begin{array}{c}0.005 \\
(0.001)\end{array}$ & $\begin{array}{c}0.02 \\
(0.001)\end{array}$ & $\begin{array}{c}0.009 \\
(0.001)\end{array}$ & - & 1972.12 & 1983.5 & - \\
\hline $\begin{array}{l}\text { UKL/DM } \\
\text { 1957.1-1998.12 }\end{array}$ & 118.99* & - & - & - & - & 1 & 1 & 1 & $\begin{array}{c}0.006 \\
(0.001)\end{array}$ & $\begin{array}{c}0.02 \\
(0.0008)\end{array}$ & - & - & 1972.4 & - & - \\
\hline
\end{tabular}

Notes.

a. $\operatorname{SupF}_{T}(1)$ is the sup F type test of no structural breaks versus the alternative hypothesis that there is $\mathrm{m}=1$ breaks. The $\operatorname{Sup} F_{T}(\ell+1 / \ell)$ are the sup $\mathrm{F}$ type tests for $\ell$ versus $\ell+1$ breaks $*, * *, * * *$ indicate significance at the $1 \%, 5 \%$ and $10 \%$, respectively.

b. SP: sequential procedure by Bai and Perron (1998, 2003); LWZ: modified Schwarz' Criterion by Liu, Wu and Zidek (1994); BIC: Bayesian Information Criteria by Yao (1988).

c. DM: Deustchemark, ATS: Austrian schilling, BFR: Belgian franc, DKR: Danish krone, PTA: Spanish peseta, FIM: Finnish markka, FF: French frank, IRL: Irish pound, LIT: Italian lira, HFL: Dutch guilder, ESC: Portuguese escudo, UKL: Pound sterling. 
Table 4. Multiple Structural Changes in Variance: Nominal Effective Exchange Rates

\begin{tabular}{|c|c|c|c|c|c|c|c|c|c|c|c|c|c|c|c|c|c|}
\hline \multirow[b]{3}{*}{ NEER } & \multicolumn{5}{|c|}{ Specifications: } & \multirow{2}{*}{\multicolumn{3}{|c|}{$\begin{array}{l}z_{t}=\{1\} \quad q=1 \\
\text { Number of Breaks }\end{array}$}} & \multirow{2}{*}{\multicolumn{5}{|c|}{$\begin{array}{lcc}p=0 \quad \varepsilon=0.15 \quad m=5 \\
\text { Final Model: Parameter Estimates }\end{array}$}} & \multirow{2}{*}{\multicolumn{4}{|c|}{ Dates }} \\
\hline & 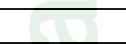 & & Tests $^{\mathrm{a}}$ & & & & & & & & & & & & & & \\
\hline & $\operatorname{SupF}_{T}(1)$ & $\operatorname{SupF}_{T}(2 / 1)$ & $\operatorname{SupF}_{T}(3 / 2)$ & $\operatorname{SupF}_{T}(4 / 3)$ & $\operatorname{SupF}_{T}(5 / 4)$ & SP & LWC & BIC & $\hat{\hat{\delta}_{1}}$ & $\hat{\delta}_{2}$ & $\hat{\delta}_{3}$ & $\hat{\delta}_{4}$ & $\hat{\delta}_{5}$ & $\hat{T_{1}}$ & $\hat{\hat{T}_{2}}$ & $\hat{T_{3}}$ & $\hat{T_{4}}$ \\
\hline $\begin{array}{c}\mathrm{DM}^{\mathrm{c}} \\
\text { 1957.1-1998.12 }\end{array}$ & $43.13^{*}$ & - & - & - & - & 1 & 0 & 2 & $\begin{array}{c}0.003 \\
(0.0005)\end{array}$ & $\begin{array}{c}0.007 \\
(0.0003)\end{array}$ & - & - & - & 1969.6 & - & - & - \\
\hline $\begin{array}{c}\text { ATS } \\
\text { 1957.1-1998.12 }\end{array}$ & $97.50^{*}$ & $9.70 * * *$ & - & - & - & 2 & 1 & 2 & $\begin{array}{c}0.002 \\
(0.0003)\end{array}$ & $\begin{array}{c}0.007 \\
(0.0004)\end{array}$ & $\begin{array}{c}0.005 \\
(0.0003)\end{array}$ & - & - & 1971.3 & 1981.10 & - & - \\
\hline $\begin{array}{c}\text { BFR } \\
\text { 1957.1-1998.12 }\end{array}$ & $119.40^{*}$ & $12.74 * *$ & - & - & - & 2 & 1 & 2 & $\begin{array}{c}0.002 \\
(0.0004) \\
\end{array}$ & $\begin{array}{c}0.009 \\
(0.0005)\end{array}$ & $\begin{array}{c}0.006 \\
(0.0004)\end{array}$ & - & - & 1971.7 & 1982.5 & - & - \\
\hline $\begin{array}{c}\text { DKR } \\
\text { 1957.1-1998.12 }\end{array}$ & 168.57 & $10.25 * *$ & - & - & - & 2 & 1 & 2 & $\begin{array}{c}0.002 \\
(0.0004)\end{array}$ & $\begin{array}{c}0.008 \\
(0.0004)\end{array}$ & $\begin{array}{c}0.006 \\
(0.0004)\end{array}$ & - & - & 1972.6 & 1983.7 & - & - \\
\hline $\begin{array}{c}\text { PTA } \\
\text { 1957.1-1998.11 }\end{array}$ & - & - & - & - & - & 0 & 0 & 0 & - & - & & - & - & - & - & - & - \\
\hline $\begin{array}{l}\text { FIM } \\
\text { 1957.1-1998.12 }\end{array}$ & $10.50^{*}$ & - & - & - & - & 1 & 0 & 0 & $\begin{array}{c}0.006 \\
(0.0007)\end{array}$ & $\begin{array}{c}0.012 \\
(0.001)\end{array}$ & - & - & - & & - & - & - \\
\hline $\begin{array}{c}\text { IRL } \\
\text { 1957.1-1998.12 }\end{array}$ & $79.06^{*}$ & - & - & - & - & 1 & 1 & 1 & $\begin{array}{c}0.003 \\
(0.0006)\end{array}$ & $\begin{array}{c}0.008 \\
(0.0004)\end{array}$ & - & - & - & 1971.10 & - & - & - \\
\hline $\begin{array}{c}\text { LIT } \\
\text { 1957.1-1998.12 }\end{array}$ & $46.12^{*}$ & $20.44^{*}$ & 1 & 1 & 3 & 1 & 1 & 3 & $\begin{array}{c}0.003 \\
(0.0007)\end{array}$ & $\begin{array}{c}0.009 \\
(0.0006)\end{array}$ & - & - & - & 1972.11 & - & - & - \\
\hline $\begin{array}{c}\text { HFL } \\
\text { 1957.1-1998.12 }\end{array}$ & $106.95^{*}$ & $9.54 * *$ & - & - & - & 2 & 1 & 2 & $\begin{array}{c}0.003 \\
(0.0004)\end{array}$ & $\begin{array}{c}0.009 \\
(0.0005)\end{array}$ & $\begin{array}{c}0.006 \\
(0.0004\end{array}$ & - & - & 1971.4 & 1981.9 & - & - \\
\hline $\begin{array}{c}\text { ESC } \\
\text { 1957.1-1998.12 }\end{array}$ & $10.77^{*}$ & $25.27^{*}$ & $25.26^{*}$ & $46.90^{*}$ & - & 4 & 0 & 1 & $\begin{array}{c}0.001 \\
(0.001)\end{array}$ & $\begin{array}{c}0.004 \\
(0.002)\end{array}$ & $\begin{array}{c}0.002 \\
(0.001)\end{array}$ & $\begin{array}{c}0.009 \\
(0.002)\end{array}$ & $\begin{array}{c}0.004 \\
(0.002)\end{array}$ & 1965.5 & 1969.1 & 1972.8 & 1977.4 \\
\hline $\begin{array}{c}\text { UKL } \\
1957.1-1998.11\end{array}$ & $90.30^{*}$ & - & - & - & - & 1 & 1 & 1 & 0.003 & 0.013 & - & - & - & 1971.10 & - & - & - \\
\hline
\end{tabular}

a. $\operatorname{Sup} F_{T}(1)$ is the sup $\mathrm{F}$ type test of no structural breaks versus the alternative hypothesis that there is $\mathrm{m}=1$ breaks. The $\operatorname{Sup} F_{T}(\ell+1 / \ell)$ are the sup $\mathrm{F}$ type tests for $\ell$ versus $\ell+1$ breaks. $*$, **, *** indicate significance at the $1 \%, 5 \%$ and $10 \%$, respectively.

b. SP: sequential procedure by Bai and Perron (1998, 2003); LWZ: modified Schwarz' Criterion by Liu, Wu and Zidek (1994); BIC: Bayesian Information Criteria by Yao (1988).

c. DM: Deustchemark, ATS: Austrian schilling, BFR: Belgian franc, DKR: Danish krone, PTA: Spanish peseta, FIM: Finnish markka, FF: French frank, IRL: Irish pound, LIT: Italian lira, HFL: Dutch guilder, ESC: Portuguese escudo, UKL: Pound sterling. 
Table 5. Multiple Structural Changes in Variance: Real Effective Exchange Rates

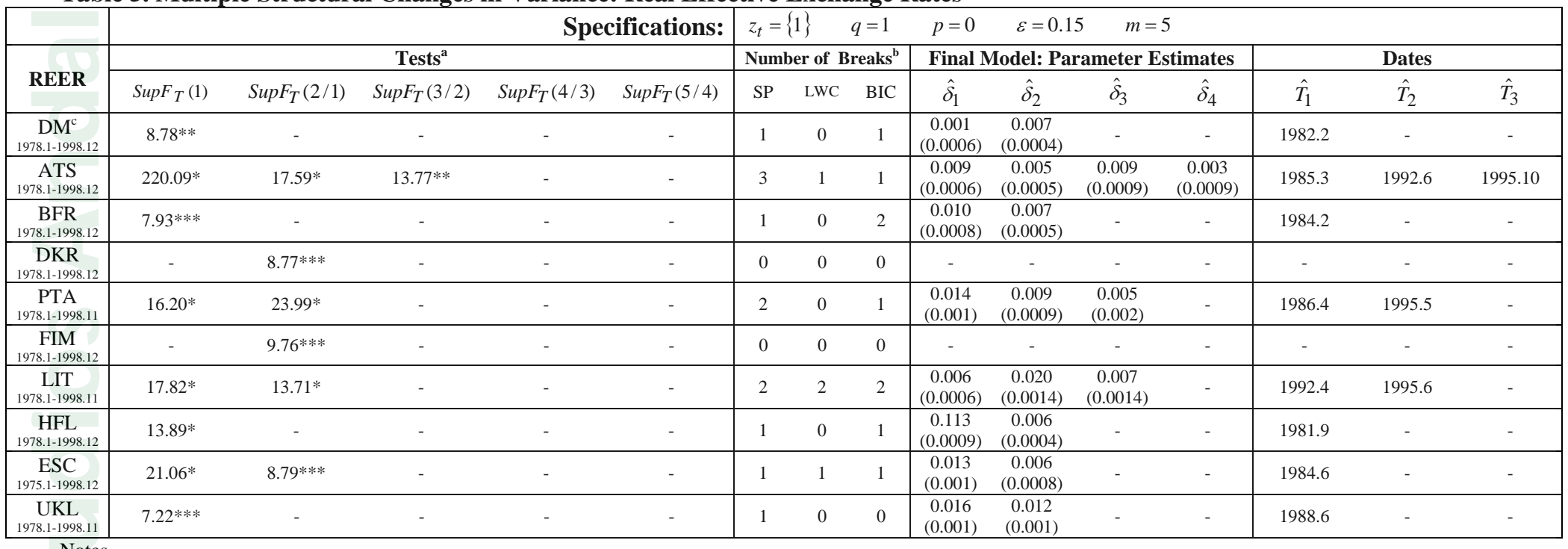

Notes.

a. $\operatorname{SupF}_{T}(1)$ is the sup F type test of no structural breaks versus the alternative hypothesis that there is $\mathrm{m}=1$ breaks. The $\operatorname{SupF}_{T}(\ell+1 / \ell)$ are the sup F type tests for $\ell$ versus $\ell+1$ breaks. $*, * *, * * *$ indicate significance at the $1 \%, 5 \%$ and $10 \%$, respectively.

b. SP: sequential procedure by Bai and Perron (1998, 2003); LWZ: modified Schwarz' Criterion by Liu, Wu and Zidek (1994); BIC: Bayesian Information Criteria by Yao (1988).

c. DM: Deustchemark, ATS: Austrian schilling, BFR: Belgian franc, DKR: Danish krone, PTA: Spanish peseta, FIM: Finnish markka, FF: French frank, IRL: Irish pound, LIT: Italian lira, HFL: Dutch guilder, ESC: Portuguese escudo, UKL: Pound sterling. 


\section{Table 6. Multiple Structural Changes in Variance: Money}

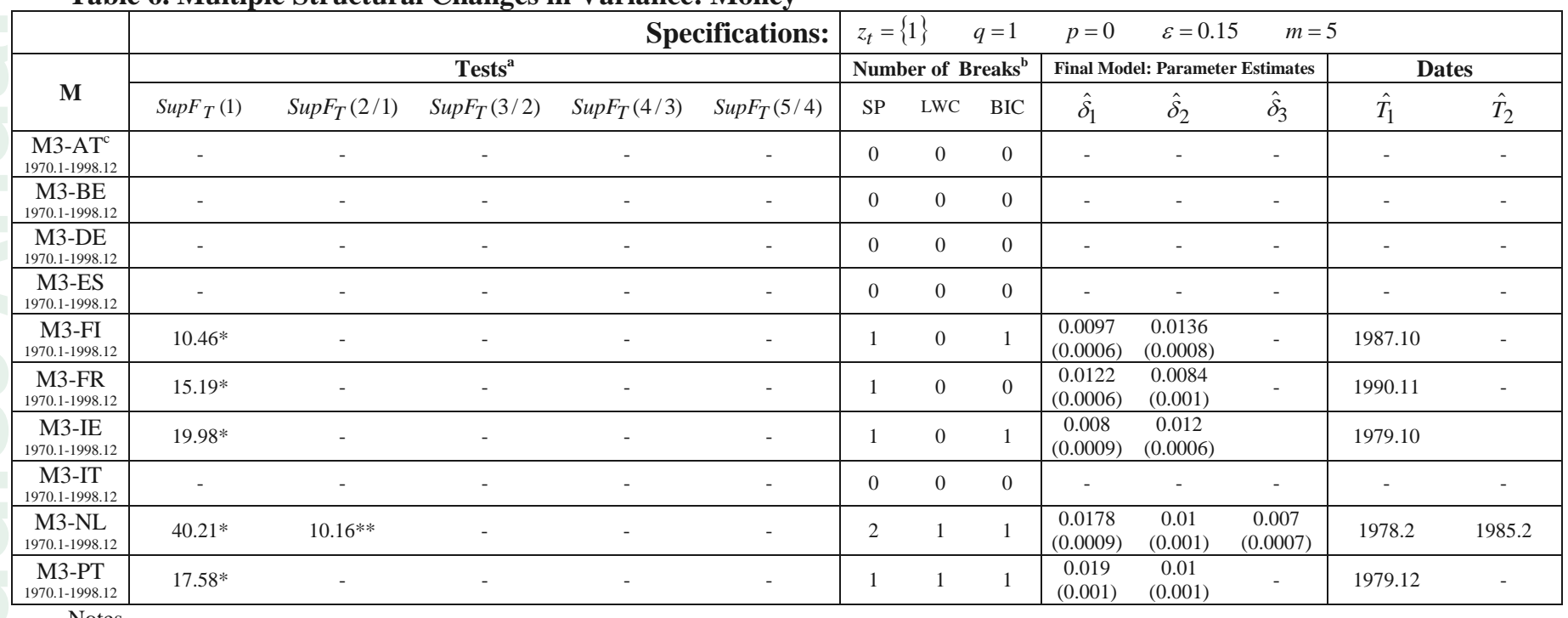

. $\operatorname{SupF}_{T}(1)$ is the sup F type test of no structural breaks versus the alternative hypothesis that there is $\mathrm{m}=1$ breaks. The $\operatorname{SupF}_{T}(\ell+1 / \ell)$ are the sup $\mathrm{F}$ type tests for $\ell$ versus $\ell+1$ breaks. *,**,*** indicate significance at the $1 \%, 5 \%$ and $10 \%$, respectively.

b. SP: sequential procedure by Bai and Perron (1998, 2003); LWZ: modified Schwarz' Criterion by Liu, Wu and Zidek (1994); BIC: Bayesian Information Criteria by Yao (1988). c. AT: Austria, BE: Belgium, DE: Germany, ES: Spain, FI: Finland, FR: France, IE: Ireland, IT: Italy, NL: The Netherlands, PT: Portugal 
Table 7. Multiple Structural Changes in Variance: Money Market Rate

\begin{tabular}{|c|c|c|c|c|c|c|c|c|c|c|c|c|c|c|c|}
\hline \multirow[b]{3}{*}{ MMR } & \multicolumn{5}{|c|}{ Specifications: } & \multirow{2}{*}{\multicolumn{3}{|c|}{$\begin{array}{c}z_{t}=\{1\} \quad q=1 \\
\text { Number of Breaks }\end{array}$}} & \multicolumn{7}{|c|}{$m=5$} \\
\hline & \multicolumn{5}{|c|}{ Tests $^{\mathrm{a}}$} & & & & \multicolumn{4}{|c|}{ Final Model: Parameter Estimates } & \multicolumn{3}{|c|}{ Dates } \\
\hline & $\operatorname{SupF}_{T}(1)$ & $\operatorname{SupF}_{T}(2 / 1)$ & $\operatorname{SupF}_{T}(3 / 2)$ & $\operatorname{SupF}_{T}(4 / 3)$ & $\operatorname{SupF}_{T}(5 / 4)$ & SP & LWC & BIC & $\hat{\delta}_{1}$ & $\hat{\delta}_{2}$ & $\hat{\delta}_{3}$ & $\hat{\delta}_{4}$ & $\hat{T}_{1}$ & $\hat{T}_{2}$ & $\hat{T}_{3}$ \\
\hline $\begin{array}{c}\mathrm{DE}^{\mathrm{c}} \\
1960.1-1998.12\end{array}$ & $45.66^{*}$ & $31.33^{*}$ & $27.13^{*}$ & - & - & 3 & 2 & 2 & $\begin{array}{c}0.43 \\
(0.07)\end{array}$ & $\begin{array}{c}1.47 \\
(0.08)\end{array}$ & $\begin{array}{c}0.46 \\
(0.08)\end{array}$ & $\begin{array}{c}0.20 \\
(0.05)\end{array}$ & 1969.2 & 1975.9 & 1981.8 \\
\hline $\begin{array}{c}\mathrm{AT} \\
1967.1-1998.12\end{array}$ & $66.79^{*}$ & - & - & - & - & 1 & 1 & 1 & $\begin{array}{c}0.39 \\
(0.02)\end{array}$ & $\begin{array}{c}0.15 \\
(0.03)\end{array}$ & - & - & 1991.6 & - & - \\
\hline $\begin{array}{c}\mathrm{BE} \\
1957.1-1998.12\end{array}$ & $65.07^{*}$ & 72.05* & - & - & - & 2 & 2 & 4 & $\begin{array}{c}0.33 \\
(0.05)\end{array}$ & $\begin{array}{c}1.01 \\
(0.04)\end{array}$ & $\begin{array}{c}0.36 \\
(0.05)\end{array}$ & - & 1970.7 & 1987.2 & - \\
\hline $\begin{array}{c}\text { DK } \\
1972.1-1998.12 \\
\end{array}$ & $90.46^{*}$ & $37.28^{*}$ & - & - & - & 2 & 1 & 1 & $\begin{array}{l}2.52 \\
(0.12)\end{array}$ & $\begin{array}{c}0.38 \\
(0.12)\end{array}$ & $\begin{array}{c}1.03 \\
(0.16)\end{array}$ & - & 1982.4 & 1992.6 & - \\
\hline $\begin{array}{c}\text { ES } \\
1967.1-1997.12 \\
\end{array}$ & $62.52^{*}$ & - & - & - & - & 1 & 1 & 2 & $\begin{array}{l}3.09 \\
(0.17)\end{array}$ & $\begin{array}{c}0.66 \\
(0.12)\end{array}$ & - & - & 1977.3 & & \\
\hline $\begin{array}{c}\mathrm{FI} \\
\text { 1977.12-1998.12 }\end{array}$ & $33.90 *$ & - & - & - & - & 1 & 0 & 1 & $\begin{array}{c}0.54 \\
(0.04)\end{array}$ & $\begin{array}{c}0.21 \\
(0.08)\end{array}$ & - & - & 1994.2 & - & - \\
\hline $\begin{array}{c}\text { IE } \\
1978.7-1998.11\end{array}$ & $8.26^{* * *}$ & $24.83^{*}$ & - & - & - & 0 & 0 & 2 & - & - & - & - & - & - & - \\
\hline $\begin{array}{c}\text { IT } \\
\text { 1971.1-1998.12 }\end{array}$ & $8.83^{* * *}$ & $8.83^{* * *}$ & $12.31^{* *}$ & - & - & 1 & 0 & 1 & $\begin{array}{c}0.65 \\
(0.06)\end{array}$ & $\begin{array}{c}0.35 \\
(0.03)\end{array}$ & - & - & 1977.8 & - & - \\
\hline $\begin{array}{c}\mathrm{NL} \\
1959.12-1998.11\end{array}$ & $57.05^{*}$ & $46.43^{*}$ & $21.11^{*}$ & - & - & 2 & 2 & 2 & $\begin{array}{c}0.35 \\
(0.06)\end{array}$ & $\begin{array}{c}1.23 \\
(0.07) \\
\end{array}$ & $\begin{array}{c}0.25 \\
(0.06)\end{array}$ & - & 1970.11 & 1981.11 & \\
\hline $\begin{array}{c}\text { PT } \\
\text { 1983.1-1998.12 }\end{array}$ & $16.26^{*}$ & $10.00 *$ & $15.41^{*}$ & - & - & 1 & 1 & 3 & $\begin{array}{c}3.03 \\
(0.30)\end{array}$ & $\begin{array}{c}1.03 \\
(0.12)\end{array}$ & - & - & 1985.4 & - & - \\
\hline $\begin{array}{c}\text { UK } \\
\text { 1972.1-1998.12 }\end{array}$ & $19.09 *$ & $37.51^{*}$ & $24.81^{*}$ & - & - & 3 & 2 & 2 & $\begin{array}{c}0.49 \\
(0.11)\end{array}$ & $\begin{array}{c}2.27 \\
(0.13)\end{array}$ & $\begin{array}{c}0.66 \\
(0.07)\end{array}$ & $\begin{array}{c}0.32 \\
(0.11)\end{array}$ & 1977.9 & 1981.9 & 1993. \\
\hline
\end{tabular}

Notes

a. $\operatorname{SupF}_{T}(1)$ is the sup $\mathrm{F}$ type test of no structural breaks versus the alternative hypothesis that there is $\mathrm{m}=1$ breaks. The $\operatorname{Sup} F_{T}(\ell+1 / \ell)$ are the sup $\mathrm{F}$ type tests for $\ell$ versus $\ell+1$ breaks. $*, * *, * * *$ indicate significance at the $1 \%, 5 \%$ and $10 \%$, respectively.

b. SP: sequential procedure by Bai and Perron (1998, 2003); LWZ: modified Schwarz' Criterion by Liu, Wu and Zidek (1994); BIC: Bayesian Information Criteria by Yao (1988). c. DE: Germany, AT: Austria, BE: Belgium, DK: Denmark, ES: Spain, FI: Finland, FR: France, IE: Ireland, IT: Italy, NL: The Netherlands, PT: Portugal, UK: United Kingdom. 
Table 8. Multiple Structural Changes in Variance: Consumer Price

\begin{tabular}{|c|c|c|c|c|c|c|c|c|c|c|c|c|c|c|c|}
\hline \multirow{3}{*}{ CPI } & \multicolumn{5}{|c|}{ Specifications: } & \multirow{2}{*}{\multicolumn{3}{|c|}{$\begin{array}{l}z_{t}=\{1\} \quad q=1 \\
\text { Number of Breaks }\end{array}$}} & \multicolumn{7}{|c|}{$\varepsilon=0.15$} \\
\hline & \multicolumn{5}{|c|}{ Tests $^{\mathrm{a}}$} & & & & \multicolumn{4}{|c|}{ Final Model: Parameter Estimates } & \multicolumn{3}{|c|}{ Dates } \\
\hline & $\operatorname{SupF}_{T}(1)$ & $\operatorname{SupF}_{T}(2 / 1)$ & $\operatorname{SupF}_{T}(3 / 2)$ & $\operatorname{SupF}_{T}(4 / 3)$ & $\operatorname{SupF}_{T}(5 / 4)$ & SP & LWC & BIC & $\hat{\delta}_{1}$ & $\hat{\delta}_{2}$ & $\hat{\delta}_{3}$ & $\hat{\delta}_{4}$ & $\hat{T}_{1}$ & $\hat{T}_{2}$ & $\hat{T}_{3}$ \\
\hline $\begin{array}{c}\mathrm{AT}^{\mathrm{c}} \\
1957.1-1998.12\end{array}$ & $56.68^{*}$ & - & - & - & - & 1 & 1 & 1 & $\begin{array}{c}0.009 \\
(0.0004)\end{array}$ & $\begin{array}{c}0.003 \\
(0.0002)\end{array}$ & - & - & 1966.12 & - & - \\
\hline $\begin{array}{c}\mathrm{BE} \\
1957.1-1998.12\end{array}$ & - & $14.25^{*}$ & $21.63^{*}$ & - & - & 0 & 0 & 0 & - & - & - & - & - & - & - \\
\hline $\begin{array}{c}\mathrm{DE} \\
1967.1-1998.12\end{array}$ & $27.82 *$ & $14.82^{*}$ & - & - & - & 2 & 1 & 1 & $\begin{array}{c}0.006 \\
(0.0003)\end{array}$ & $\begin{array}{c}0.004 \\
(0.0004)\end{array}$ & $\begin{array}{c}0.002 \\
(0.0005)\end{array}$ & - & 1981.4 & 1990.11 & - \\
\hline $\begin{array}{c}\text { ES } \\
1957.1-1998.12\end{array}$ & $146.29 *$ & $9.85 * * *$ & - & - & - & 2 & 1 & 1 & $\begin{array}{c}0.01 \\
(0.0003)\end{array}$ & $\begin{array}{c}0.005 \\
(0.0006)\end{array}$ & $\begin{array}{c}0.004 \\
(0.0003)\end{array}$ & - & 1977.9 & 1983.12 & - \\
\hline \begin{tabular}{|c|}
$\mathrm{FI}$ \\
$1957.1-1998.12$ \\
\end{tabular} & $58.07 *$ & - & - & - & - & 1 & 1 & 2 & $\begin{array}{c}0.006 \\
(0.0002)\end{array}$ & $\begin{array}{c}0.003 \\
(0.0002) \\
\end{array}$ & - & - & 1977.7 & - & - \\
\hline $\begin{array}{c}\text { FR } \\
\text { 1957.1-1998.11 }\end{array}$ & $33.28^{*}$ & $60.82 *$ & $15.53^{*}$ & - & - & 3 & 2 & 3 & $\begin{array}{c}0.006 \\
(0.0003)\end{array}$ & $\begin{array}{c}0.003 \\
(0.0002)\end{array}$ & $\begin{array}{c}0.005 \\
(0.0002)\end{array}$ & $\begin{array}{c}0.002 \\
(0.0002)\end{array}$ & 1963.3 & 1973.11 & 1983.3 \\
\hline $\begin{array}{c}\text { IT } \\
\text { 1957.1-1998.12 }\end{array}$ & $206.32 *$ & 24.33* & $21.18^{*}$ & - & - & 2 & 1 & 1 & $\begin{array}{c}0.007 \\
(0.0002)\end{array}$ & $\begin{array}{c}0.002 \\
(0.0003)\end{array}$ & $\begin{array}{c}0.004 \\
(0.0004)\end{array}$ & - & 1983.1 & 1992.4 & - \\
\hline $\begin{array}{c}\text { NL } \\
1957.1-1998.12\end{array}$ & $44.96 *$ & $12.47^{*}$ & - & - & - & 2 & 1 & 1 & $\begin{array}{c}0.009 \\
(0.0005)\end{array}$ & $\begin{array}{c}0.004 \\
(0.0004)\end{array}$ & $\begin{array}{c}0.003 \\
(0.0003)\end{array}$ & - & 1964.12 & 1977.3 & - \\
\hline \begin{tabular}{|c|} 
PT \\
1957.1-1998.12 \\
\end{tabular} & 90.69* & $24.25^{*}$ & $20.97 *$ & - & - & 2 & 1 & 1 & $\begin{array}{c}0.013 \\
(0.0006) \\
\end{array}$ & $\begin{array}{c}0.004 \\
(0.001) \\
\end{array}$ & $\begin{array}{c}0.006 \\
(0.001) \\
\end{array}$ & - & 1985.1 & 1992.7 & - \\
\hline $\begin{array}{c}\text { UK } \\
\text { 1957.1-1998.12 }\end{array}$ & $53.73^{*}$ & - & - & - & - & 1 & 1 & 2 & $\begin{array}{c}0.006 \\
(0.0003)\end{array}$ & $\begin{array}{c}0.004 \\
(0.0003)\end{array}$ & - & - & 1980.3 & - & - \\
\hline
\end{tabular}

a. $\operatorname{SupF}_{T}(1)$ is the sup $\mathrm{F}$ type test of no structural breaks versus the alternative hypothesis that there is $\mathrm{m}=1$ breaks. The $\operatorname{SupF}_{T}(\ell+1 / \ell)$ are the sup $\mathrm{F}$ type tests for $\ell$ versus $\ell+1$ breaks $*, * *, * * *$ indicate significance at the $1 \%, 5 \%$ and $10 \%$, respectively.

b. SP: sequential procedure by Bai and Perron (1998, 2003); LWZ: modified Schwarz' Criterion by Liu, Wu and Zidek (1994); BIC: Bayesian Information Criteria by Yao (1988).

c. AT: Austria, BE: Belgium, DE: Germany, ES: Spain, FI: Finland, FR: France, IE: Ireland, IT: Italy, NL: The Netherlands, PT: Portugal, UK: United Kingdom. 
Table 9. Multiple Structural Changes in Variance: Nominal Exchange Rates, Sub-periods

\begin{tabular}{|c|c|c|c|c|c|c|c|c|c|c|c|c|c|}
\hline \multirow[b]{3}{*}{ NER } & & & & \multicolumn{3}{|c|}{ Specification: } & $z_{t}=\{1\}$ & $q=1$ & $p=0$ & \multicolumn{2}{|c|}{$\varepsilon=0.20$} & $m=3$ & \\
\hline & \multicolumn{3}{|c|}{ Tests $^{\mathrm{a}}$} & \multicolumn{3}{|c|}{ Number of Breaks ${ }^{\mathrm{b}}$} & \multicolumn{4}{|c|}{ Final Model: Parameter Estimates } & \multicolumn{3}{|c|}{ Dates } \\
\hline & $\operatorname{SupF}_{T}(1)$ & $\operatorname{SupF}_{T}(2 / 1)$ & $\operatorname{SupF}_{T}(3 / 2)$ & SP & LWC & BIC & $\hat{\delta}_{1}$ & $\hat{\delta}_{2}$ & $\hat{\delta}_{3}$ & $\hat{\delta}_{4}$ & $\hat{T}_{1}$ & $\hat{T}_{2}$ & $\hat{T}_{3}$ \\
\hline \multicolumn{14}{|l|}{$\mathrm{ATS} / \mathrm{DM}^{\mathrm{c}}$} \\
\hline $1957.1-1979.2$ & $11.60^{*}$ & $8.067 * * *$ & - & 2 & 0 & 1 & $0.002(0.0004)$ & $0.005(0.0006)$ & $0.005(0.0007)$ & - & 1968.3 & 1974.5 & - \\
\hline $\begin{array}{l}1979.3-1994.12 \\
1995.1-1998.12\end{array}$ & $16.64 *$ & - & - & 1 & 0 & 0 & $0.002(0.0002)$ & $0.0008(0.004)$ & - & - & 1991.3 & - & - \\
\hline \multicolumn{14}{|l|}{ BFR/DM } \\
\hline $1957.1-1979.2$ & $25.83^{*}$ & $7.07 * * *$ & - & 2 & 1 & 1 & $0.002(0.0004)$ & $0.007(0.0006)$ & $0.004(0.0007)$ & - & 1968.4 & 1974.5 & - \\
\hline 1979.3-1998.12 & $8.06^{*}$ & $24.29 *$ & - & 2 & 0 & 1 & $0.007(0.0008)$ & $0.003(0.0005)$ & $0.002(0.0007)$ & - & 1983.3 & 1994.2 & - \\
\hline \multicolumn{14}{|l|}{ DKR/DM } \\
\hline $1957.1-1979.2$ & $35.61^{*}$ & $6.73^{* * *}$ & & 2 & 1 & 1 & $0.002(0.0006)$ & $0.007(0.0009)$ & $0.009(0.0009)$ & - & 1967.10 & 1973.5 & - \\
\hline $1979.3-1998.12$ & $23.57 *$ & (2) & - & 1 & 0 & 0 & $0.005(0.0004)$ & $0.002(0.0008)$ & $0.005(0.0000)$ & - & 1994.5 & - & - \\
\hline \multicolumn{14}{|l|}{ PTA/DM } \\
\hline $1957.1-1979.2$ & $11.31^{*}$ & - & - & 1 & 0 & 0 & $0.009(0.001)$ & $0.023(0.002)$ & - & - & 1973.4 & - & - \\
\hline 1979.3-1989.5 & & - & - & & & 0 & $0.017(0.001)$ & $0.010(0.001)$ & - & - & 1983.6 & - & - \\
\hline $1989.6-1998.12$ & $25.32 *$ & - & - & 1 & 0 & 2 & $0.013(0.001)$ & $0.004(0.002)$ & - & - & 1995.12 & - & - \\
\hline \multicolumn{14}{|l|}{ FIM/DM } \\
\hline 1957.1-1979.2 & - & - & - & 0 & 0 & 0 & - & - & - & - & - & - & - \\
\hline 1979.3-1996.9 & - & - & - & 0 & 0 & 0 & - & 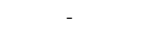 & - & - & - & - & - \\
\hline $1996.10-1998.12$ & - & - & - & 0 & 0 & 0 & - & - & - & - & - & - & - \\
\hline \multicolumn{14}{|l|}{ FF/DM } \\
\hline 1957.1-1979.2 & $13.54^{*}$ & - & - & 1 & 0 & 0 & $0.008(0.001)$ & $0.016(0.002)$ & - & - & 1973.5 & - & - \\
\hline $1979.3-1998.12$ & (n) & - & - & 0 & 0 & 0 & (1) & - & - & - & & & \\
\hline \multicolumn{14}{|l|}{ IRL/DM } \\
\hline $1957.1-1979.2$ & $61.88^{*}$ & & - & 1 & 1 & 1 & $0.005(0.001)$ & $0.021(0.001)$ & & & 1973.5 & & \\
\hline 1979.3-1998.12 & $30.92^{*}$ & $6.89 * * *$ & - & 2 & 1 & 1 & $0.006(0.0008)$ & $0.003(0.001)$ & $0.012(0.001)$ & - & 1988.12 & 1993.1 & - \\
\hline \multicolumn{14}{|l|}{ LIT/DM } \\
\hline 1957.1-1979.2 & \begin{tabular}{ll|l|}
$83.82^{*}$ & \\
\end{tabular} & $14.61^{*}$ & - & 2 & 1 & 1 & $0.004(0.001)$ & $0.007(0.002)$ & $0.02(0.002)$ & - & 1968.3 & 1973.1 & - \\
\hline $1979.3-1992.9$ & - & - & - & 0. & 0 & 0 & - & $-a_{0}$ & - & - & - & - & - \\
\hline $1992.10-1998.12$ & & - & - & & & & & & - & - & & & - \\
\hline \multicolumn{14}{|l|}{ HFL/DM } \\
\hline 1957.1-1979.2 & $25.83^{*}$ & & - & 1 & 1 & 1 & $0.002(0.0004)$ & $0.006(0.0005)$ & & - & 1968.6 & & \\
\hline $1979.3-1998.12$ & $8.06 * * *$ & $24.30 *$ & - & 2 & 0 & 1 & $0.007(0.0008)$ & $0.003(0.0005)$ & $0.001(0.0007)$ & - & 1983.3 & 1994.2 & - \\
\hline \multicolumn{14}{|c|}{$0.007(0.0000) \quad 0.00(0.0000)=0.01(0.007)$} \\
\hline 1957.1-1979.2 & $14 . .22^{*}$ & - & - & 1 & 1 & 1 & $0.005(0.0009)$ & $0.016(0.001)$ & - & - & 1973.1 & - & - \\
\hline 1979.3-1992.3 & & - & - & 0 & 0 & 0 & ( & & - & - & $-a_{0}$ & - & - \\
\hline \multicolumn{14}{|l|}{ UKL/DM } \\
\hline 1957.1-1979.2 & $39.48^{*}$ & - & - & 1 & 1 & 1 & $0.005(0.001)$ & $0.021(0.002)$ & - & - & 1972.5 & - & - \\
\hline $1979.3-1990.9$ & $\mathrm{C}_{\mathrm{C}}$ & - & - & 0 & 0 & 0 & 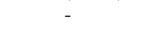 & & - & - & 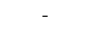 & - & - \\
\hline $\begin{array}{r}1990.10-1992.9 \\
1992\end{array}$ & $972 *$ & - & - & 0 & 0 & 0 & $0014(0002)$ & $\begin{array}{c}- \\
0\end{array}$ & - & - & - & - & - \\
\hline 1992.10-1998.12 & $9.72^{*}$ & & & 1 & 0 & 1 & $0.014(0.002)$ & & & & 1996.8 & & \\
\hline
\end{tabular}

a. $\operatorname{Sup} F_{T}(1)$ is the sup $\mathrm{F}$ type test of no structural breaks versus the alternative hypothesis that there is $\mathrm{m}=1$ breaks. The $\operatorname{Sup} F_{T}(\ell+1 / \ell)$ are the sup $\mathrm{F}$ type tests for $\ell$ versus $\ell+1$ breaks. $*, * *, * * *$ indicate significance at the $1 \%, 5 \%$ and $10 \%$, respectively.

b. SP: sequential procedure by Bai and Perron (1998, 2003); LWZ: modified Schwarz' Criterion by Liu, Wu and Zidek (1994); BIC: Bayesian Information Criteria by Yao (1988).

c. DM: Deustchemark, ATS: Austrian schilling, BFR: Belgian franc, DKR: Danish krone, PTA: Spanish peseta, FIM: Finnish markka, FF: French frank, IRL: Irish pound, LIT: Italian lira, HFL: Dutch guilder, ESC: Portuguese escudo, UKL: Pound sterling. 
Table 10. Multiple Structural Changes in Variance: Nominal Effective Exchange Rates, Sub-periods

\begin{tabular}{|c|c|c|c|c|c|c|c|c|c|c|c|c|c|}
\hline \multirow[b]{3}{*}{ NEER } & & & & \multicolumn{3}{|c|}{ Specification: } & $z_{t}=\{1\}$ & $q=1$ & $p=$ & \multicolumn{2}{|c|}{$\varepsilon=0.20$} & \multicolumn{2}{|c|}{$m=3$} \\
\hline & \multicolumn{3}{|c|}{ Tests $^{\mathrm{a}}$} & \multicolumn{3}{|c|}{ Number of Breaks ${ }^{b}$} & \multicolumn{4}{|c|}{ Final Model: Parameter Estimates } & \multicolumn{3}{|c|}{ Dates } \\
\hline & $\operatorname{SupF}_{T}(1)$ & $\operatorname{SupF}_{T}(2 / 1)$ & $\operatorname{SupF}_{T}(3 / 2)$ & SP & LWC & BIC & $\hat{\delta}_{1}$ & $\hat{\delta}_{2}$ & $\hat{\delta}_{3}$ & $\hat{\delta}_{4}$ & $\hat{T}_{1}$ & $\hat{T}_{2}$ & $\hat{T}_{3}$ \\
\hline \multicolumn{14}{|l|}{$\mathrm{DM}^{\mathrm{c}}$} \\
\hline $1957.1-1979.2$ & $23.07 *$ & - & - & 1 & 1 & 1 & $0.004(0.0006)$ & $0.010(0.0008)$ & - & - & 1971.11 & - & - \\
\hline$\frac{1979.3-1998.12}{\text { ATS }}$ & \multicolumn{12}{|c|}{ ATS } & \\
\hline 1957.1-1979.2 & $37.99 *$ & - & - & 1 & 1 & 1 & $0.002(0.0003)$ & $0.007(0.0005)$ & - & - & 1971.4 & - & - \\
\hline 1979.3-1994.12 & $986 * * *$ & - & - & 0 & 0 & 0 & $0006(00006$ & - $0003(0001)$ & - & - & 199710 & - & - \\
\hline \multicolumn{14}{|l|}{ BFR } \\
\hline 1957.1-1979.2 & $67.72^{*}$ & - & - & 1 & 1 & 1 & $0.002(0.0003)$ & $0.009(0.0005)$ & - & - & 1971.9 & - & - \\
\hline $1979.3-1998.12$ & -1 & - & - & 0 & 0 & 0 & & & - & - & $x^{-1}$ & - & - \\
\hline \multicolumn{14}{|l|}{ DKR } \\
\hline $\begin{array}{c}1957.1-1979.2 \\
1979.3-1998.12\end{array}$ & $\begin{array}{l}64.98^{*} \\
10.86^{* * *}\end{array}$ & - & - & $\begin{array}{l}1 \\
1\end{array}$ & $\begin{array}{l}1 \\
0\end{array}$ & $\begin{array}{l}1 \\
1\end{array}$ & $\begin{array}{l}0.002 \\
0.009\end{array}$ & $\begin{array}{l}0.007 \\
0.006\end{array}$ & - & - & $\begin{array}{l}1972.7 \\
1983.8\end{array}$ & - & - \\
\hline \multicolumn{14}{|l|}{ PTA } \\
\hline $1957.1-1979.2$ & - & - & - & 0 & 0 & 0 & - & - & - & - & - & - & - \\
\hline 1979.3-1989.5 & - & - & - & 0 & 0 & 0 & - & - & - & - & - & - & - \\
\hline 1989.6-1998.12 & $7.68 * * *$ & - & - & 1 & 0 & 2 & $0.009(0.0009)$ & $0.004(0.001)$ & 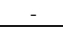 & - & 1995.7 & - & - \\
\hline \multicolumn{14}{|l|}{ FIM } \\
\hline 1957.1-1979.2 & & & & 0 & 0 & 0 & & & & - & & & - \\
\hline 1979.3-1996.9 & $20.25 *$ & - & - & 1 & 1 & 1 & 0.005 (0.0009) & $0.014(0.001)$ & - & - & 1991.10 & - & \\
\hline $1996.10-1998.12$ & 20.25 & - & - & 0 & 0 & 0 & $0.000(0.0000)$ & $0.014(0.001)$ & 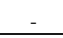 & - & 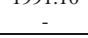 & - & - \\
\hline \multicolumn{14}{|l|}{ IRL } \\
\hline $1957.1-1979.2$ & $31.78^{*}$ & - & - & 1 & 1 & 1 & $0.003(0.0005)$ & $0.009(0.0007)$ & & - & 1971.12 & & - \\
\hline \multirow{2}{*}{\multicolumn{14}{|c|}{ LIT }} \\
\hline & & & & & & & & & & & & & \\
\hline $1957.1-1979.2$ & $26.50^{*}$ & - & - & 1 & 1 & 1 & $0.003(0.002)$ & $0.013(0.002)$ & - & - & 1972.12 & - & - \\
\hline 1979.3-1992.9 & & - & - & 0 & 0 & 0 & & & - & - & 1996.4 & - & - \\
\hline 1992.10-1998.12 & $20.60^{*}$ & - & - & 1 & 0 & 1 & $0.017(0.0004)$ & $0.005(0.0005)$ & 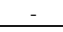 & - & & & \\
\hline \multicolumn{14}{|l|}{ HFL } \\
\hline $1957.1-1979.2$ & $47.32^{*}$ & - & - & 1 & 1 & 1 & $0.003(0.0004)$ & $0.009(0.0005)$ & & - & 1971.8 & - & - \\
\hline $1979.3-1998.12$ & (1) & - & - & 0 & 0 & 0 & - & - & - & - & - & - & - \\
\hline \multicolumn{14}{|l|}{ ESC } \\
\hline 1957.1-1979.2 & $10.18^{* *}$ & $25.31^{*}$ & - & 2 & 0 & 1 & 0.011 & 0.003 & 0.007 & - & $\begin{array}{l}1965.7 \\
\end{array}$ & 1972.9 & - \\
\hline $\begin{array}{c}1979.3-1992.3 \\
1992.4-1998.12\end{array}$ & $7.75 * * *$ & - & - & $\begin{array}{l}0 \\
1\end{array}$ & $\begin{array}{l}0 \\
0\end{array}$ & $\begin{array}{l}0 \\
0 \\
0\end{array}$ & 0.007 & 0.004 & - & - & 1997.7 & - & - \\
\hline \multicolumn{14}{|l|}{$\begin{array}{c}1992.4-1990.12 \\
\text { UKL }\end{array}$} \\
\hline 1957.1-1979.2 & $27.28^{*}$ & - & - & 1 & 1 & 1 & 0.003 & 0.011 & - & - & 1971.11 & - & - \\
\hline 1979.3-1990.9 & - & - & - & - & - & - & $-x_{0}$ & - & - & - & - & - & - \\
\hline $\begin{array}{l}1990.10-1992.9 \\
199210-198.12\end{array}$ & -0 & 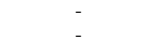 & 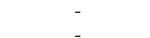 & - & 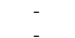 & - & & - & - & - & - & - & - \\
\hline
\end{tabular}

a. $\operatorname{Sup} F_{T}(1)$ is the sup $\mathrm{F}$ type test of no structural breaks versus the alternative hypothesis that there is $\mathrm{m}=1$ breaks. The $\operatorname{Sup} F_{T}(\ell+1 / \ell)$ are the sup $\mathrm{F}$ type tests for $\ell$ versus $\ell+1$ breaks. $*, * *, * * *$ indicate significance at the $1 \%, 5 \%$ and $10 \%$, respectively.

b. SP: sequential procedure by Bai and Perron (1998, 2003); LWZ: modified Schwarz' Criterion by Liu, Wu and Zidek (1994); BIC: Bayesian Information Criteria by Yao (1988).

c. DM: Deustchemark, ATS: Austrian schilling, BFR: Belgian franc, DKR: Danish krone, PTA: Spanish peseta, FIM: Finnish markka, FF: French frank, IRL: Irish pound, LIT: Italian lira, HFL: Dutch guilder, ESC: Portuguese escudo, UKL: Pound sterling. 
Table 11. Multiple Structural Changes in Variance: Money Market Rate, Sub-periods

\begin{tabular}{|c|c|c|c|c|c|c|c|c|c|c|c|c|c|}
\hline \multirow[b]{3}{*}{ MMR } & & & & \multicolumn{3}{|c|}{ Specification: } & $z_{t}=\{1\}$ & $q=1$ & $p=0$ & $\varepsilon=0.20$ & \multicolumn{2}{|c|}{$m=3$} & \\
\hline & \multicolumn{3}{|c|}{ Tests $^{\mathrm{a}}$} & \multicolumn{3}{|c|}{ Number of Breaks ${ }^{\mathrm{b}}$} & \multicolumn{4}{|c|}{ Final Model: Parameter Estimates } & \multicolumn{3}{|c|}{ Dates } \\
\hline & $\operatorname{SupF}_{T}(1)$ & $\operatorname{SupF}_{T}(2 / 1)$ & $\operatorname{SupF}_{T}(3 / 2)$ & SP & LWC & BIC & $\hat{\delta}_{1}$ & $\hat{\delta}_{2}$ & $\hat{\delta}_{3}$ & $\hat{\delta}_{4}$ & $\hat{T}_{1}$ & $\hat{T}_{2}$ & $\hat{T}_{3}$ \\
\hline \multicolumn{14}{|l|}{$\mathrm{DE}^{\mathrm{c}}$} \\
\hline $\begin{array}{c}1972.1-1979.2 \\
1979.3-1998.12\end{array}$ & $\begin{array}{l}15.33^{*} \\
15.98^{*}\end{array}$ & $17,42 *$ & $21.31 *$ & 1 & $\begin{array}{l}1 \\
1\end{array}$ & $\begin{array}{ll}1 \\
1\end{array}$ & $\begin{array}{l}2.196(0.256) \\
0.46(0.034)\end{array}$ & $\begin{array}{l}0.548(0.181) \\
0.131(0.034)\end{array}$ & $0.296(0.028)$ & $0.177(0.027)$ & $\begin{array}{l}1974.5 \\
1783.1\end{array}$ & 1986.12 & 19928 > $>$ C \\
\hline \multicolumn{14}{|c|}{ (1) } \\
\hline $\begin{array}{l}1972.1-1979.2 \\
1979.3-1994.12\end{array}$ & $21.65^{*}$ & - & - & $\begin{array}{l}1 \\
0\end{array}$ & $\begin{array}{l}0 \\
0 \\
0\end{array}$ & $\begin{array}{l}0 \\
0\end{array}$ & $0.418(0.030)$ & $0.207(0.028)$ & - & - & 1991.8 & - & - \\
\hline \multicolumn{14}{|l|}{$\mathrm{BE}$} \\
\hline $1972.1-1979.2$ & & & - & 0 & 0 & 0 & & & & - & & & - \\
\hline $1979.3-1998.12$ & $50.86^{*}$ & $21.18^{*}$ & - & 2 & 1 & 1 & $1.111(0.068)$ & $0.582(0.099)$ & $0.269(0.070)$ & - & 1987.3 & 1991.2 & - \\
\hline \multicolumn{14}{|l|}{ DK } \\
\hline $\begin{array}{r}1972.2-1979.2 \\
1979.3-1998.12 \\
\end{array}$ & $44.03^{*}$ & 48.83* & - & $\begin{array}{l}0 \\
2\end{array}$ & $\begin{array}{l}0 \\
2\end{array}$ & $\begin{array}{l}0 \\
2\end{array}$ & $2.333(0.137)$ & $0.321(0.088)$ & $1.039(0.107)$ & - & 1983.1 & 1992.7 & \\
\hline \multicolumn{14}{|c|}{$2.000(0.10), 0.021(0.000) \quad 1.0000(0.10)$} \\
\hline 1972.1-1979.2 & $22.82^{*}$ & - & - & 1 & 0 & 1 & $2.549(0.233)$ & $1.110(0.398)$ & - & - & 1977.4 & - & - \\
\hline $\begin{array}{r}1979.3-1989.5 \\
\end{array}$ & - & - & - & 0 & 0 & 0 & $\frac{-}{0657(0866)}$ & 0 & - & - & $\overline{-}$ & - & - \\
\hline \multicolumn{14}{|l|}{ FI } \\
\hline $\begin{array}{c}1979.3-1996.9 \\
1996.10-1998.12\end{array}$ & $13.65^{*}$ & $14.71^{*}$ & - & $\begin{array}{l}2 \\
0\end{array}$ & $\begin{array}{l}0 \\
0\end{array}$ & $\begin{array}{l}2 \\
0\end{array}$ & $0.391(0.048)$ & $0.836(0.083)$ & $0.288(0.082)$ & & 1989.8 & 1993.2 & - \\
\hline$\frac{\mathrm{IE}}{\mathrm{IE}}$ & $839 * *$ & $24,29 *$ & $1719 *$ & 3 & 1 & 1 & $1622(0.410)$ & $0762(0360)$ & $0.351(0.423)$ & $2566(0333)$ & 19834 & 19889 & 19928 > 20 \\
\hline \multicolumn{14}{|c|}{ 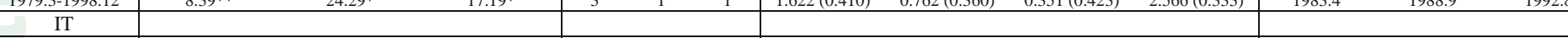 } \\
\hline 1972.1-1979.2 & $15.51^{*}$ & $14.85^{*}$ & - & 2 & 0 & 2 & 0.237 & 1.130 & 0.327 & - & 1974.1 & 1976.10 & - \\
\hline 1979.3-1992.9 & $7.30^{* * * *}$ & - & - & 1 & 0 & 0 & 0.273 & 0.427 & - & - & 1986.1 & - & - \\
\hline 1992.10-1998.12 & - & - & - & 0 & 0 & 0 & & & - & - & & - & - \\
\hline \multicolumn{14}{|l|}{ NL } \\
\hline $\begin{array}{l}1972.1-1979.2 \\
\end{array}$ & & - & - & 0 & 0 & 0 & & & - & & & - & - \\
\hline 1979.3-1998.11 & $14.91 *$ & - & - & 1 & 1 & 1 & $0.775(0.067)$ & $0.254(0.034)$ & $=$ & - & 1983.3 & & - \\
\hline \multicolumn{14}{|c|}{ (1) } \\
\hline $\begin{array}{l}1983.1-1992.3 \\
1992.4-1998.12\end{array}$ & $15.67 *$ & $14.00^{*}$ & - & $\begin{array}{l}3 \\
0\end{array}$ & $\begin{array}{l}1 \\
0\end{array}$ & $\begin{array}{l}2 \\
0\end{array}$ & $2.808(0.275)$ & $0.4861(0.223)$ & $2.063(0.347)$ & - & 1985.5 & 1990.5 & - \\
\hline \multicolumn{14}{|l|}{ UK } \\
\hline 1972.1-1979.2 & $13.88^{*}$ & - & - & 1 & 1 & 1 & $0.441(0.103)$ & $1.626(0.175)$ & - & - & 1977.4 & - & - \\
\hline 1979.3-1990.9 & $21.15^{*}$ & - & - & 1 & 1 & 1 & $2.670(0.228)$ & $0.699(0.112)$ & & & 1981.5 & - & - \\
\hline $1990.10-1992.9$ & $10.37 *$ & $=0$ & - & 1 & 1 & 2 & $0.346(0.725)$ & $0.062(0.080)$ & & & 1991.12 & - & - \\
\hline $1992.10-1998.12$ & $8.56 * *$ & $12.55 * *$ & ( & 2 & 1 & 1 & $0.841(0.097)$ & $0.497(0.082)$ & $0.231(0.060)$ & - & 1993.12 & 1995.9 & - \\
\hline
\end{tabular}

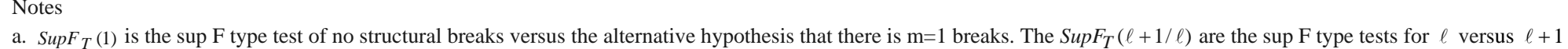
a. $\operatorname{Sup} F_{T}(1)$ is the sup $\mathrm{F}$ type test of no structural breaks versus the alternative
breaks. $*, * *, * * *$ indicate significance at the $1 \%, 5 \%$ and $10 \%$, respectively.

b. SP: sequential procedure by Bai and Perron (1998, 2003); LWZ: modified Schwarz' Criterion by Liu, Wu and Zidek (1994); BIC: Bayesian Information Criteria by Yao (1988).

c. DE: Germany, AT: Austria, BE: Belgium, DK: Denmark, ES: Spain, FI: Finland, IE: Ireland, IT: Italy, NL: The Netherlands, PT: Portugal, UK: United Kingdom. 
Table 12. Multiple Structural Changes in Variance: Consumer Price, Sub-periods

\begin{tabular}{|c|c|c|c|c|c|c|c|c|c|c|c|c|c|}
\hline \multirow{3}{*}{ CPI } & & & & \multicolumn{3}{|c|}{ Specification: } & $z_{t}=\{1\}$ & $q=1$ & $p=0$ & $\varepsilon=0.20$ & \multicolumn{2}{|c|}{$m=3$} & \\
\hline & \multicolumn{3}{|c|}{ Tests $^{\mathrm{a}}$} & \multicolumn{3}{|c|}{ Number of Breaks ${ }^{\mathbf{b}}$} & \multicolumn{4}{|c|}{ Final Model: Parameter Estimates } & \multicolumn{3}{|c|}{ Dates } \\
\hline & $\operatorname{SupF}_{T}(1)$ & $\operatorname{SupF}_{T}(2 / 1)$ & $\operatorname{SupF}_{T}(3 / 2)$ & SP & LWC & BIC & $\hat{\delta}_{1}$ & $\hat{\delta}_{2}$ & $\hat{\delta}_{3}$ & $\hat{\delta}_{4}$ & $\hat{T}_{1}$ & $\hat{T}_{2}$ & $\hat{T}_{3}$ \\
\hline \multicolumn{14}{|l|}{$\mathrm{AT}^{\mathrm{C}}$} \\
\hline $1957.1-1979.2$ & $52.24^{*}$ & - & - & 1 & 1 & 1 & $0.009(0.0005)$ & $0.003(0.0005)$ & - & - & 1967.1 & - & - \\
\hline 1979.3-1994.12 & & - & - & 0 & 0 & 0 & & & - & - & & - & - \\
\hline 1995.1-1998.12 & - & - & - & 0 & 0 & 0 & & - & - & - & - & - & - \\
\hline \multicolumn{14}{|l|}{$\mathrm{BE}$} \\
\hline $\begin{array}{c}1957.1-1979.2 \\
1979.3-1998.12\end{array}$ & $21.46 *$ & - & - & $\begin{array}{l}0 \\
1\end{array}$ & $\begin{array}{l}0 \\
1\end{array}$ & $\begin{array}{l}0 \\
1\end{array}$ & $0.004(0.0002)$ & $0.002(0.0001)$ & - & - & $\overline{1984.2}$ & - & - \\
\hline \multicolumn{14}{|l|}{ DK } \\
\hline 1957.1-1979.2 & & $1000 *$ & - & 0 & 0 & 0 & & & & - & & & - \\
\hline 1979.3-1998.12 & $17.57 *$ & $10.10^{* *}$ & - & 2 & 1 & 1 & $0.004(0.003)$ & $0.003(0.0003)$ & $0.002(0.0003)$ & - & 1986.7 & 1993.1 & - \\
\hline \multicolumn{14}{|c|}{ 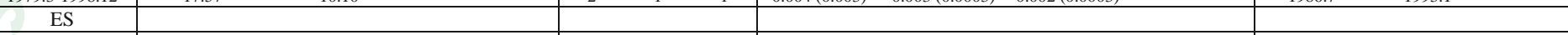 } \\
\hline $1957.1-1979.2$ & $11.50^{*}$ & - & - & 1 & 0 & 1 & $0.011(0.006)$ & $0.008(0.0005)$ & - & - & 1965.5 & - & - \\
\hline $1979.3-1989.5$ & 11.00 & $=$ & - & 0 & 0 & 0 & $0.011(0.000)$ & $0.000(0.0005)$ & - & $=$ & 1900.5 & $=$ & - \\
\hline \multirow{2}{*}{\multicolumn{14}{|c|}{$\mathrm{FI}$}} \\
\hline & & & & & & & & & & & & & \\
\hline 1957.1-1979.2 & & & & 0 & 0 & 0 & & & & & & & \\
\hline 1979.3-1996.9 & $8.48 * *$ & - & - & 1 & 0 & 1 & $0.004(0.0003)$ & $0.003(0.0002)$ & - & - & 1983.6 & - & - \\
\hline \multirow{2}{*}{\multicolumn{14}{|c|}{$\mathrm{FR}$}} \\
\hline & & & & & & & & & & & & & \\
\hline $\begin{array}{l}1957.1-1979.2 \\
1979.3-1978.12\end{array}$ & $23.49^{*}$ & $12.54^{*}$ & $16.59 *$ & 3 & 1 & 1 & $0.007(0.0004)$ & $0.004(0.0003)$ & $0.002(0.0004)$ & $0.003(0.0003)$ & 1961.6 & 1968.4 & 1972.12 \\
\hline \multicolumn{14}{|l|}{ IT } \\
\hline $1957.1-1979.2$ & & & & 0 & 0 & 0 & & & & & & & \\
\hline $1979.3-1992.9$ & $50.48^{*}$ & - & - & 2 & 1 & 1 & $0.008(0.0004)$ & $0.002(0.0002)$ & - & - & 1982.11 & & - \\
\hline $1992.10-1998.12$ & $35.54 *$ & - & - & 1 & 1 & 1 & $0.002(0.0002)$ & $0.005(0.0003)$ & - & - & 1996.5 & - & - \\
\hline \multicolumn{14}{|l|}{ NL } \\
\hline $\begin{array}{l}1957.1-1979.2 \\
1979.2\end{array}$ & $32.73^{*}$ & - & - & 1 & 1 & 1 & $0.009(0.0006)$ & $0.004(0.0004)$ & - & - & 1965.1 & - & - \\
\hline \multicolumn{14}{|l|}{$\frac{19 / 9.3-1998.12}{\mathrm{PT}}$} \\
\hline $1957.1-1979.2$ & & & & 0 & 0 & 0 & & & & & & & \\
\hline 1979.3-1992.3 & $37.68^{*}$ & - & - & 1 & 1 & 1 & $0.011(0.0007)$ & $0.004(0.0006)$ & - & - & 1985.2 & - & - \\
\hline 1992.4-1998.12 & $19.17 *$ & - & - & 1 & 1 & 1 & $0.004(0.0005)$ & $0.007(0.0003)$ & - & - & 1994.4 & - & - \\
\hline \multicolumn{14}{|l|}{ UK } \\
\hline $1957.1-1979.2$ & - & - & - & 0 & 0 & 0 & & & & - & - & - & - \\
\hline $1979.3-1990.9$ & - & $=$ & $=$ & 0 & 0 & 0 & & & - & $=$ & $=$ & $=$ & - \\
\hline $\begin{array}{r}1990.10-1992.9 \\
199210-1998.12\end{array}$ & - & - & - & $\begin{array}{l}0 \\
0\end{array}$ & $\begin{array}{l}0 \\
0\end{array}$ & $\begin{array}{l}0 \\
0\end{array}$ & 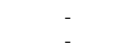 & - & - & - & - & - & - \\
\hline
\end{tabular}

Notes

a. $\operatorname{SupF}_{T}$ (1) is the sup F type test of no structural breaks versus the alternative hypothesis that there is $\mathrm{m}=1$ breaks. The $\operatorname{SupF}_{T}(\ell+1 / \ell)$ are the sup $\mathrm{F}$ type tests for $\ell$ versus $\ell+1$ breaks. $*, * *, * * *$ indicate significance at the $1 \%, 5 \%$ and $10 \%$, respectively.

b. SP: sequential procedure by Bai and Perron (1998, 2003); LWZ: modified Schwarz' Criterion by Liu, Wu and Zidek (1994); BIC: Bayesian Information Criteria by Yao (1988) c. AT: Austria, BE: Belgium, DK: Denmark, ES: Spain, FI: Finland, FR: France, IT: Italy, NL: The Netherlands, PT: Portugal, UK: United Kingdom. 